\title{
Kamu Yönetiminin Değişimi ve Azerbaycan Yerel Yönetimler Sistemi Üzerindeki Etkisi
}

\author{
The Change of Public Administration and Its Impact on Azerbaijan Local Governments System
}

\section{Murteza HASANOĞLU}

Doç. Dr., Azerbaycan Devlet İdarecilik Akademisi,

m_hasanoglu@yahoo.com.tr

https://orcid.org/0000-0003-3734-4045
Makale Başvuru Tarihi / Received: 16.11.2018

Makale Kabul Tarihi / Accepted: 09.05.2019

Makale Türü / Article Type: Araştırma Makalesi

\section{Anahtar \\ Kelimeler:}

Azerbaycan,

Küreselleşme,

Demokrasi,

Kamu Yönetimi,

Yerel Yönetimler,

Keywords:

Azerbaijan,

Globalisation,

Democracy,

Public

Administration,

Local Governments,

\section{ÖZET}

Ülkeler, tercih ettikleri siyasal sistem her ne olursa olsun, idari yapılarında yerel yönetimlere yer vermektedirler. Ancak yerel yönetimlerin sahip olduğu güç, yetki, sorumluluk ve görev alanı ile organizasyon yapıları ülkelere göre farklılıklar gösterir. Yerel yönetimler, ülkelerin idari yapısı içerisinde yer alıp, "yerel" ve "ortak" düzeydeki kamu hizmetlerini sunmak üzere yetkilendirilen, karar organları halk tarafindan seçilen, özerk kamu tüzel kişileridir. Demokrasinin yerleşikliği, devlet şekli (federal, üniter) ne olursa olsun bütün ülkelerde yerel yönetimlerin gücü ve etkinliği ile doğru orantılıdır. Hatta çoğu zaman ülkelerin ekonomik gelişmişlik düzeyi ile yerel yönetimlerin gücü de doğru orantılıdır. Kısacası yerel yönetimlerin etkinlik düzeyi ile yerel demokrasi, demokratikleşme ve iktisadı kalkınma arasında doğru orantılı bir ilişki vardır. Hatta yerel yönetimlerin aksi görüşlere rağmen ülke bütünlüğ̈̈nün sağlanmasına da önemli katkılar sağlamaktadırlar. Çünkü yönetim ve katılım ile kendi kendini yöneten halk, kendini geliștirerek milli bütünlüğe entegre olmaktadır. Azerbaycan, 1991 yılında SSCB'nin dă̆llması ile bağımsızlı̆̆ını elde etmiş yeni bir devlettir. Tarihsel süreçte ilk önce Çarlık Rusya'sının, sonrasında ise Sovyetler Birliği'nin işgali altında varlığını devam ettirmiştir. Bu çalışma, yerel yönetimlerin Azerbaycan'da ortaya çıkması ve gelişerek bugünkü yapıya gelmesindeki önemli iç ve dış etmenler ile mevzuatsal dönüşümü tarihsel süreçleri içerisinde ortaya koymayı amaçlamaktadır.

\section{ABSTRACT}

Whatever their politcal systems are, all the countries have local administrations in their administrative structures. However, in every country there are differences with regard to the power, authority, responsibility areas and struktures of the local administrations. Local administrations within the unity of the country administration system are the public juristic persons, which provides services for the people and of which organs are chosen by the people. In all the federal, unitary countries there is a paralel between the efficiency and power of the local administrations and the culture of democracy. Even there is a paralel between the power of the local administrations and the economic development of the country. In sum; there is a paralel between the local administration and local democracy and economic development and democratization. Even though there are contrary arguments, local administrations have important functions in the protection of the state's integrity. Because self-governing people develop themselves with participation to administration and they become integrated to the nation. Azerbaijan is a young country that had its independence after the disintegration of the Soviet Union in 1991. Azerbaijan was first under the body of the Tsarist Russia then the Soviet Union. This study aims to examine significant inner and outer factors that causing local governmentsin Azerbaijan coming out from past to present; and put forth legislative regulations that local governments in Azerbaijan passing on in order to come to present situation. 


\section{GIRISS}

Konum olarak Avrasya'nın merkezinde yer alan Kafkasya ve Orta Asya bölgeleri Soğuk Savaşın sona ermesiyle birlikte başlayan yeni dönemde jeopolitik konumu ve doğal kaynakları ile tüm dünyanın dikkatini çekmektedir. Dolayısıyla bu bölgedeki ülkelerin gelişmeleri ve sistemsel dönüşümleri de dünya devletleri tarafından yakından takip edilmektedir. Bu bölgede yer alan devletler gelişmiş dünya devletlerini de örnek alarak toplumsal dinamiklerine göre yönetsel ve sistemsel yapılarını yeni şartlara göre dönüştürmektedirler. Bu coğrafyada bulunan ve önemli bir bölgesel aktör olan Azerbaycan da bağımsızlığını kazandıktan sonra diğer alanlarda olduğu gibi kamu yönetimi alanında da dönüşümler yaşamış ve yeni politikalar uygulamaya başlamıştır.

Sovyetler Birliği'nin dağılması ile bölgede yaşayan topluluklar bağımsızlıklarını ilan ederek yeni devletler kurmuşlardır. Bu yeni süreçte kurulan devletlerden beş tanesi de halkı etnik olarak Türk olan devletlerdir. Yeni kurulan bu Cumhuriyetler milli devlet olma sürecine girmiş, bu doğrultuda da yönetim yapılarını oluşturarak millileşme politikalarını hayata geçirmeye başlamışlardır. Daha önce SSCB'ye bağlı olan bu devletler, Sovyet rejiminin çöküşü esnasında sırasıyla egemenliklerini ve bağımsızlıklarını ilan etmişlerdir. Bu ülkeler bağımsız devlet statüsünün kazanılmasıyla birlikte verlıklarını devam ettirebilmek için bir taraftan "merkezi planlı ekonomiden piyasa ekonomisine geçiş" yaparak ekonominin yeniden yapılanması yoluna gitmişler; diğer taraftan da "demokratik ilkeler" ve "hukukun üstünlüğ̈̈"ne dayalı yeni bir devlet yapısı kurulmasını esas alımışlardır.

Azerbaycan Cumhuriyeti bağımsızlığını ilan ettikten sonra devletin temel yapısını ve işleyişini düzenlemek adına bir anayasa ihdas etmiştir. Gelişen ihtiyaca göre de zamanla anayasa maddeleri üzerinde muhtelif güncellemelere gidilmiştir. Yerel yönetimler ile ilgili düzenlemeler ve bu düzenlemelere esas reform düşüncesi son yıllarda Azerbaycan Cumhuriyeti'nin en fazla gündeminde olan konuların başında gelmektedir. Bu sebeple gündemde olan bu konu üzerinde çalışmamız inşa edilecektir.

Günümüzde gerçekleşen teknolojik gelişmeler dünyanın her alanda değişimini gündeme getirmiş; ekonomik, siyasal ve sosyal yapılarda yeniden oluşum sürecine girilmiştir. Hem devletler hem örgütler bu değişim süreci karşısında çalışma biçimlerini, üretim şekillerini, amaçlarını ve sonuçta da örgütlenme şekillerini geliştirmeye mecbur kalmışlardır. Bu süreçte rekabet, ulusal ve uluslar arası alanda kalite kavramını ön plana çıkarmıştır. Bu bağlamda kaliteye ulaşmak hedefi örgütlere sürekli değişmek ve sürekli kendilerini geliştirmek zorunluluğu getirmiştir.

Örgütlerin, içinde bulundukları toplumun gereksinimlerini karşılamak üzere kurulmaları ve kuruldukları çevrenin ürünü olmaları nedeniyle çevrelerinde gerçekleşen hızlı ve sürekli değişim karşısında kayıtsız kalmaları mümkün değildir. Aksi halde varlıklarını sürdürmeleri konusunda problemler ortaya çıkacaktır. Hatta, artık örgütlerin değişim sürecine ayak uydurmaları yüksek verimlilik ve etkinlik için yeterli görülmemekte, yenilik ve değişim kaynağı haline gelip, getirdikleri yenilikleri çevrelerine benimsetmeleri gereğinden söz edilmektedir.

Tüm dünyada nüfusun hızla artması, kentleşme, tarımsal üretim alanlarındaki değişiklikler, ülkeler arasındaki gelir düzeyi farklılıklarının artışı, aynı şekilde ülkeler içinde gelir dağılımındaki eşitsizlikler, kıt kaynakların verimsiz ve dengesiz kullanımından kaynaklanan yeni kaynak arayışları ve insanların daha yüksek standartlarda yaşam talepleri değişim ve gelişmeyi gerekli kılan etkenler olarak kabul edilebilir.

Çalışmamızda, yönetimi sürekli olarak değişim ve gelişim yönünde zorlayan nedenler üzerinde durulacaktır. Bu kapsamda örgütsel yapılardaki değişim unsuru genel olarak ele alınacaktır. Bununla birlikte örgütsel/kurumsal yapılarda değişim ihtiyacını hızlandıran ve çok yönlü hale getiren küreselleşme olgusuna değinilecektir. Küreselleşminin kavramsal çerçevesi, tarihsel süreci, yönetim sistemleri ve toplum üzerine olan etkisi ele alınacaktır. Yerel yönetimler ile demokrasi ve katılım ilişkisi ortaya konularak, Azerbaycan Cumhuriyeti yönetim yapısında meydana gelen değişim ve dönüşüm üzerinde durulacaktır. Bu kapsamda öncelikle Azerbaycan'da yeni Anayasa ile yaşanan devletin yeniden yapılandırılması süreci kısaca anlatılacaktır. Sonrasında ise yerel yönetimlerin mevcut yapısı ve bu hususta düzenlenmesi gereken alanlar üzerinde değerlendirmelerde bulunulacaktır. Bu bağlamda çalışmanın temel amacı, küreselleşme ekseninde Azerbaycan Cumhuriyeti'ndeki yerel yönetimlerin değişim ve dönüşümünün analiz edilmesidir. 


\section{2. ÖRGÜTSEL DEĞIŞiM NEDİR?}

Kişi, birim veya örgüt (organizasyon) şeklindeki bir sistemin, sürecin veya durumun planlı ya da plansız bir şekilde mevcut formundan başka bir forma dönüştürülmesi "değişme" olarak tanımlanmaktadır. Değişme; kendisi ile ilgili eylemler ile ilgili ilkeler, kuramlar, süreçler ve değerlendirmelerde değişimin yönünün, boyutunun, sonuçlarının ve yorumunun ayrı ayrı algılanmasını ortaya koyacak şekilde tanımlanmıştır. Değişme olgusu tüm toplumsal yapılar için sürekli nitelikte meydana gelen kaçınılmaz bir döngüdür. Bu sebeple evrensel bir niteliğe sahiptir. Örgütler kendi içerisinde kişi ve gruplardan oluşmaktadır. Bununla birlikte içerisinde yer aldığı yerel, bölgesel, ulussl ve hatta uluslararası çevre ile de etkileşim içerisindedir. Bu sebeple her ne kadar birimsel ve işgören bazında değişimler ölçülse de diğer faktörlerden tamamen ayrı olarak bağımsız bir değerlendirmede bulunulamaz. Örgütler ulusal/uluslararası mevzuat değişiklikleri, yeni teknoloji kullanımı, değişen pazar/hizmet şartları, arz/talep ilişkisi gibi etkenlerden doğrudan etkilendikleri için yeni durum ve şartlara uyum sağlama ve avantajlı konuma geçme baskısını daha yoğun bir şekilde üzerlerinde hissetmektedirler. Toplam maliyetlerin azaltılması, verimlilik ve etkinliğin arttırılmasına yönelik ortaya çıkan bu baskı, işgörenlerin örgüt içerisinde bir araç (makine - üretim unsuru) olmaktan öte düşünen, gelişen, geliştiren ve bu sebeple de değer verilmesi gereken bir unsur olarak (hem araç - hem amaç) değerlendirilmesi beklentisine neden olmuştur (Peker, 1995:1-3).

Örgütsel değişim asıl olarak örgütte yer alan insan unsuruna bağlıdır. Özellikle örgütsel değişimin planlı değişme yöntemi ile gerçekleştirilmesi halinde insan unsurunun önemi daha da çok artmaktadır. Örgütsel değişme sadece örgüt çalışanları ile ilgişkili değildir. Bu sebeple çalışanların kişisel değişim derecelerinin toplamı örgütsel değişimi ortaya koymaz. Ancak bununla birlikte çalışanların çalışma esasları ile ilgili kişisel zihniyet değişimlerinin toplamı ve sonucu örgütün değişim derecesini önemli ölçüde etkilemektedir. Bu sebeple örgütsel değişimin, kişisel değişmenin sonunda gerçekleşeceği söylenebilir (Terlemez, 2001:237).

Siyasi iktidarın kaynă̆ının halka dayandırıldığı teorilerinin hayata geçirilmesiyle birlikte halkın bu siyasi iktidarın oluşumu, değiştirilmesi ve denetimine doğrudan ya da örgütleri aracıllı̆̆ ile çeşitli düzeylerde ve ölçülerde zaman içinde yoğunluğu giderek artan bir şekilde katılmaya başladığı ve sonuçta bu halk kitlelerinin yani yönetilenlerin siyasal sürece katılma hakkına sahip oldukları anlayışının gelişerek yerleştiği görülmektedir.

Katılım kavramı, bu kavramla özdeşleştirilen çeşitli anlamları olması dolayısıyla çoğu zaman tartışma konusu olmuş, buna siyasal gelişmenin göstergesi olarak bakan yaklaşımı benimseyenler yanında, kişisel çözümleme düzeyinde kişiyi siyasal gösterilerde yer alma, sorunlarını karar alma mercilerine iletme ve oy verme neden ve koşullarını araştıran yaklaşımı benimseyenler de olmuştur.

Katılmayı devlet yönetimine katılma olarak tanımlayan Cem Eroğul'a göre; katılmanın tarihteki ilk örneğini veren Eski Yunun Site devletlerindeki doğrudan demokrasi uygulamasından günümüze kadar katılmanın, İngiltere, Amerika, 1789'da Fransa, 1917'de Rusya'da yaşanan devrimler dizisini izleyen ve Doğu Bloku'nun çöküşü ve küreselleşme ile birlikte dünyada yaygınlaşan bir süreç geçirdiği ve önemini giderek arttırdığı söylenebilir (Eroğul, 1999:19-31).

\section{KÜRESELLEŞME KAVRAMININ TANIMI VE TARİHI}

XXI. yüzyılın en dikkat çeken özelliği, tüm dünyada belirgin bir şekilde gözlemlenen kümülatif değişim sürecinin bu çağa etkin ve hızlı bir şekilde girmiş olmasıdır. Küreselleşmenin etkisiyle yönetim sistemleri ve alt unsurlarında bir takım değişim ve dönüşümler yaşanmıştır. Bu gelişmelere esas olarak uluslararası yönetim modelleri ile organizasyon yapısında meydana gelen örgütsel değişim, "iyi yönetimin" yeniden keşfedilmesine sebep olmuştur. Yüzyıllardır insanların zihninde mevcut olan ve "gelecekteki zaman" olarak tasavvur edilen simgesel tarihsel döneme, başdöndürücü teknolojik gelişmeler, akıllara durgunluk veren ekonomik imkanlar, köklü sosyo-kültürel ve politik dönüşümler ile girmiş durumdayız. Bu sürecin yaşanmasına neden olan en temel etken şüphesiz "küreselleşme" olgusudur.

Küreselleşme kavramı taşıdığı önem nedeniyle birçok bilim dalı tarafından multidisipliner olarak incelenmektedir. Bu sebeple de popüler olarak akademik yazında kendisine geniş bir yer edinmiştir. Ancak buna rağmen küreselleşme kavramının tüm disiplinleri kapsayıcı ve herkes tarafından kabul edilen, bütüncül, genel ve kesin bir tanımı bulunmamaktadır. her disiplin ve araştırmacı tarafından küreselleşmenin faklı yönleri ve etkileri dikkate alınarak muhtelif tanımlar ortaya konulmuştur. 
Küreselleşme kavramı; "yeni bir dünya düzeninin değil fakat yeni dünya düzensizliğinin, hatta üst üste gelen ve rekabet halindeki otoritelerin, çoklu bağlllkkların ve kimliklerin, prizmatik uzay ve inanç nosyonlarının oluşturduğu "yeni bir ortaçă̆" işaretçisi olarak görülebilir" (Bağçe, 1999:9), şeklinde tanımlanabilir. Bu ve benzeri tanımlardan harekete küreselleşme; tüm dünyanın bütünsel olarak tek bir mekan şekline dönüşebilecek ölçüde sıkışıp küçülmesi sürecini ifade etmektedir (Tutar, 2000:18). Küreselleşme kavramının "süreç" yanında "olgu" olarak tanımlanması da söz konusudur. ZENGİNGÖNÜL'e (2004:12) göre küreselleşme tanımlarının ortak özelliği "ortak bir tanım üzerinde anlaşmaya varamamalarıdır".

OECD’nin küreselleşmeyi ifade etmek için önerdiği tanımda üç ana unsur bulunmaktadır (Hasanoğlu, 2001:70);

- Enformasyon ve iletişim alanlarında bilgisayar teknolojisinin hızla yayılması,

- Siyasal arenada "ulusaşırı şirketler" gibi yeni ve güçlü aktörlerin etkin hale gelmesi,

- Ülkelerin çoğunda de-regülasyon politikalarının benimsenmesi ve hayata geçirilmesi.

MODELSKI'ye göre küreselleşme; "dünyanın büyük medeniyetleri arasındaki artan bağlantının tarihidir". Bu düşünceden hareketle küreselleşme, tarihsel olarak en eski medeniyetler arasındaki düzensiz aralıklarla meydana gelen karşılaşmalara (etkileşimlere) kadar uzanan, uzun vadeli bir süreçtir. Küreselleşme kavramı siyasal topluluklar, uluslar ve uygarlıklar arasındaki genel nitelikteki dayanışma olgusunun derinleşmesinin ve genişlemesinin tarihsel sürecini içerir (Held ve Mcgrew, 2008:71).

Karışık, geniş kapsamlı ve çok yönlü olan "küreselleşme", günümüz uygarlıklarının temel dinamizmini ortaya çıkaran bir katalizör olarak görülmesinin yanı sıra birçok eleştiriye de maruz kalmaktadır. Küreselleşme olgusunu olumlu yönde algılayıp açıklamaya çalışan "küreselciler" ve kavramı olumsuzluklarla donatan "antiküreselciler" konuya farklı açılardan bakarak birbirinden farklı sonuçlara ulaşmaktadırlar.

Küreselleşmeye karşı olumlu bir tavır alan "küreselciler", kavramı; sosyal, siyasal, ekonomik ve kültürel değerlerin ve bu değerlere esas olarak meydana gelen birimlerin ulusal sınırlar dışına taşarak tüm dünyaya yayılması ile devletler arasındaki ekonomik ve fiziksel bağımsızlığın törpülenmesi olarak ifade ederler. Bu yaklaşımdan hareketle küreselleşme, farklı toplumlara ait inanç ve kültürlerin herkez tarafından çok daha yakından tanınması; ideolojik ayrımlara dayalı kutupların ortadan kalkması; devletler arasındaki ilişkilerin çok yönlü olarak yoğunlaşması ve yaygınlaşması sonuçlarını doğuran kaçınılmaz bir süreçtir.

Küreselleşme "anti-küreselcilere" göre ise; batılı devletlerin, soğuk savaş dönemi sonrasında kazanmış olduğu galibiyetini farklı bir şekilde bütün dünyaya yaymasıdır. Bu bağlamda uluslararası sermayenin yani çok uluslu şirketlerin egemenliği dünya genelinde tekelleşerek zorunlu-etkin hale gelmektedir. Dolayısıyla küreselleşmeyi "emperyalizmin yeni yüzü" olarak ifade etmek mümkündür.

Bir çok yazarın ifade ettiği görüşe göre küreselleşme, etkinlik, hakimiyet ve gücünü ekonominin genel işleyişinden yani başka bir ifadeyle ulusal/uluslararası ekonomik yasalardan ve kuruluşlardan aldığı yönündedir. $\mathrm{Bu}$ görüşe göre küreselleşmenin ilk boyutunu ekonomi oluşturmaktadır. Çünkü ekonomi bireylerin ve toplumların çözmesi gereken birincil sorundur. Siyasi iktidarlara karşı yapılan zorlamalar ile ekonomik ve yönetsel açıdan dünya hakimiyeti kurma amacı ve düşüncesinin küreselleşme ile ön plana çıktığı yaygın bir görüştür (Sağlam, 2007:7).

Küreselleşme ister bir olgu ister bir süreç olarak ele alınsın, "devlet” üzerinde çok önemli ve geri dönülemez etkilere yol açmış ve devletin yapısal ve işlevsel görünümünde ciddi düzeyde değişmelere neden olmuştur. Bu değişimin boyutu her ulusal devlet için farklı düzeyde olsa da, kesin olan küresel etkilerden her ulus devletin belli ölçüde nasibini aldığıdır. Küreselleşme ve yaşanan büyük değişim kamu yönetiminin uygulamalarında oldukça etkili olmuştur. Bu bağlamda devletin yeniden yapılandırılması, devletin küçültülmesi, kamu hizmeti anlayışındaki değişim, kamu yönetiminde işletmecilik anlayışı, yönetişim, yerelleşme ve özelleştirme gibi yöntemler tartış1lmaya başlamıştır (Akçakaya, 2017:108-109).

Küreselleşmenin, her geçen gün daha da çok artan büyük bir ticaret akışı ile ülkelerin ekeonomik sınırlarının ortadan kalkarak sermaye yatırımlarının hayata geçirildiği açık bir uluslararası sistem olduğunu esas alırsak; böyle bir sistemin, ilişki türünün uluslararası ticari faaliyetlerin tarihi açısından yeni değildir. 19. yüzyılın ikinci yarısından itibaren birbiri ile bütünleşmiş bir dünya ticaret sistemi varlığını ortaya koymuştur. Bu nedenle küreselleşmenin (özelde ekonomik açıdan) son 10-20 yılda ortaya çıktığı iddiası gerçeği yansıtmamaktadır. 19. yüzyılda birçok şirketin yerel, bölgesel ve ulusal sınırları aşarak küreselleşmesi bu durumun basit bir ispatıdır. Hatta "Doğu Hindistan Şirketi" gibi 18. yüzyılda küreselleşen firmaların varlığı da bu ispatı kuvvetlendirmektedir. 
Küreselleşme genel olarak çok boyutlu bir olgu olup, insanların yaklaşımlarına ve ilgi alanlarına göre yönetsel, siyasal, sosyal, kültürel ve ekonomik yönleriyle hayatlarına girmektedir. Küreselleşmenin uygulamada kendisini göstermesi çok daha önce olmasına rağmen sonuçlarının ortaya çıkması ve herkes tarafından gözlemlenerek ortaya konulması, kavramlaştırılıp disipline edilmesi oldukça yenidir. Bu bağlamda "küresel" kavramı ilk kez "Komünikasyonda Patlamalar (1960)" isimli kitap içerisinde "Marshall Meluhan" tarafindan in, , bu yeni süreç için "Global Köy" terimini kullanması ile literatüre girmiştir. Kavram, 1980'lere doğru Harvard, Stanford, Colombia gibi prestijli Amerikan işletme okullarında kullanılmaya başlanmış ve yine bu çevrelerden çıkmış bazı ekonomistler tarafından güncelleştirilmiştir. Aynı yıllarda uluslararası ekonomik kurulların yayınlarında ve raporlarında da kullanılmaya başlanılmıştır (Tutar, 2000:21).

1945 ile1975 yılları arasında coğrafi mekan olarak dünyanın önemli bir kısmı serbest pazar ilişkilerine açılmıştır. Bu dönemde 1945 öncesinden çok daha farklı yeni bir dünya ticaret alanı meydana gelmiştir. İleri kapitalist ekonomik yapıya sahip ülkelerdeki sermaye, çok daha serbest bir şekilde hareket edebileceği yeni bir zemine kavuşmuştur. Buradan hareketle kapitalizme yani serbest pazar ekonomisine entegre olan ülkelerin sayısında hızlı bir artış meydana gelmiştir. Başka bir ifadeyle "üçüncü dünya" olarak sınıflandırılan ülkelerin kapitalist sisteme geçmesi ve sistemin bu ülkelerde gelişmesi ivme kazanmıştır. Bu dinamik, 1980'li yıllardan itibaren küreselleşmeyi şekillenecek olan en önemli faktörlerden birisi olarak kabul edilebilir (Büyükbaykal, 2004:19).

1980'lerin sonlarından itibaren iktidar olan yeni liderler küreselleşme seçeneğini siyasi çıkarlarına da uygun olduğu için desteklemişlerdir. Burada siyasi çıkar ile kastedilen; seçilmek ve iktidarda kalmaktır. Bu dönemde birçok yeni liderin iktidara gelmesi ya da mevcut iktidarını devam ettirmesi, ülke ekonomilerinin düşüşe geçmesi, hatta çoğu zaman çökmesi sonrasında söz konusu olmuştur. Bu çöküntü üzerine iktidara gelmelerine müteakip ülkenin ekonomik koşullarını ciddi biçimde iyileştirerek iktidarlarını güçlendirmişlerdir (Castells, 2005:180-181).

1980'li yıllardan sonra dünya genelinde küreselleşmenin sürekli olarak hızlandığı; buna bağlı olarak ta yerel ve bölgesel entegrasyonların arttı̆̆ görülmektedir. Küreselleşme sürecinin temel dinamikleri olan iletişim, teknik, teknolojik, ulaştırma vd. alanlarda yaşanan hızlı gelişmeler ile dünya giderek daha küçük bir hale gelmiştir. Küreselleşmeye bağlı olarak yaşanan bu gelişmeler özellikle bölgesel işbirliği ve entegrasyon çalışmalarında ülkelerin idari, siyasi ve ekonomik yapılarını yeniden gözden geçirmeleri ve yeniden yapılanma çalışmalarına girmelerini gündeme getirmiştir. Örneğin Avrupa Konseyince kabul edilen 1985 tarihli Avrupa Yerel Yönetimler Ö̈zerklik Şartı kapsamında yerinden yönetim anlayışına (yerindelik - subsidiarity) yeni bir boyut getirilmiştir. Avrupa Birliğinde de 1992 Maastricht Anlaşması' ile bölgeselleşmeye vurgu yapılarak ekonomik ve siyasi bütünleşmenin tamamlanması ve para birliğine doğru hızlı bir yönelme eğilimi ortaya çıkmıştır. Avrupa Birliği tarafından kabul edilen Avrupa Tek Senedi'nde yerellik ilkesi açıkça ifade edilmemiştir. Ancak senedde bunu çağrıştıran ifadelere yer verilmiştir (Doğan, 2016:87).

\section{YÖNETIM KURAMLARI}

Yönetimin başlangıcı insanlık tarihiyle başlar. Tarihte yönetim sorunlarının anlatıldığı, ele alındığı belgelere sıkça rastlanmaktadır. Tarih boyunca büyük kaleler, yollar, Mısır Piramitleri gibi görkemli yapılar ve düzenli ve büyük orduların kurulması, bunların örgütlenmesi başarılı yönetim örneklerindendir.

Yönetimle ilgili ilk kitaplar ise hükümdarlara öğütler vermek amacıyla yazılmış kitaplardır. Bunların en bilinen örnekleri ise; Aristo'nun Politika's1, Platon'un Cumhuriyet'i, Machiavelli'nin Prens'ini sayabiliriz. Yine 11. yüzyılda da yaşamış Türk devlet adamı Nizam-ül Mülk'ün Siyasetname’si devlet yönetimi alanında yazılmış ögüt veren kitaplardandır.

Yönetimin bilimsel yöntemlerle incelenmesi ise çok yenidir. Yönetim alanındaki ilk bilimsel araştırmalar ise 1800'lü yılların sonu ile 1900'lü yılların başlangıcında olmuştur. ABD Başkanlığı da yapmış olan Woodrow Wilson'un 1887 yılında yazmış olduğu "Yönetimin İncelenmesi" isimli makale yönetim alanında dünyada yayınlanmış ilk bilimsel eser olarak kabul edilmektedir. Bu makalenin yayınlanmasından itibaren yönetimin bilimsel olarak ele alınması hızlanıştır. WILSON makalesinde federal yönetim sisteminde yapılması gereken temel reformlardan bahsetmiştir. Personel sisteminde yaşanan bazı sorunlar Wilson gibi birçok yazarın yönetim ile politikanın birbirinden kesin olarak ayrılması gerektiği düşüncesini savunmaya yöneltmiştir (Tortop, 1993:14). 
Sanayileşmenin başlaması, üretimin artırılmasının gerekliliği, küçük atölye üretiminden daha büyük ve aile dış1 işçilerin çalıştı̆̆ üretim alanlarının oluşması, yönetimde yeni yol ve yöntemlerin arayışlarını hızlandırdı. 20 . Yüzyılın en önemli yaklaşımlarından ilki "Bilimsel Yönetim Yaklaşımı" olmuştur.

\subsection{Bilimsel Yönetim Yaklaşımı}

Bu yaklaşıma başta Herrington Emerson, Henry Gantt, Frank ve Lillian Gilberth olmak üzere birçok kişi önemli ölçüde katkılar sağlamıştır. Ancak bu yaklaşımın en bilinen, önemli ismi şüphesiz F.W.Taylor'dur (Özkalp ve Kırel, 2001:17). Taylor çalışmasının temelini fabrikada yapılan işlerin nasıl daha hızlı yapılabileceği üzerine kurdu. Burada Taylor daha çok kendi çalıştığ 1 ve diğer işyerlerindeki gözlemlerinden yararlanmıştır.

Taylor gözlemlerinde;

- İşyerlerinde verimsiz çalışıldığını,

- İşçilerin tembel ve az çalışmaya yatkın olduğunu,

- İşçilerin işleri kendi bildikleri gibi yaptıklarını,

- İşçilerin yeteneklerine göre işlerde çalışmadıkları ve

- Yönetimin de işler için standart süreler belirlemediği sonucuna ulaşmıştır.

Taylorizm veya Bilimsel Yönetim Yaklaşımının ana ilkeleri şunlardır (Peker, 1995:73);

- Örgütsel faaliyetlerde belirsiz, gelişigüzel bir çalışma usulü yerine bilimsel usullere uygun çalışmalıdır.

- Örgütsel faaliyetler gelişigüzel ve rastlantısal olarak değil, bir düzen içerisinde birbiri ile uyumlu, tutarlı ve eşgüdümlü şekilde gerçekleştirilmelidir.

- Örgütsel amaç ve hedeflerin hayata geçirilmesinde işgörenlerin birbirinden bağımsız olarak kişisel faaliyette bulunmaları yerine karşılıklı işbirliği ve yardımlaşma içerisinde çalışmaları gerekir.

- Örgütsel faaliyetlerde düşük verim yerine maksimum verimlilik esas alınmalıdır.

- Örgütsel faliyet içerisindeki tüm inani unsurlardan maksimum verim alınabilmesi için sürekli olarak işbaşında eğitim faaliyetleri gerçekleştirilmelidir.

Taylor insanların (çalışanların) sadece para ile motive olabileceğini düşünerek parça başı ödemeyi önermiştir. $\mathrm{Bu}$ yöntem her ne kadar üretimi artırsa da insanları robotlaştırmaya çalıştı̆̆ iç̧in eleştirilmiştir. Yine işin parçalara ayrılması önerisi işçileri adeta makinalaştırmıştır.

Bugünde çağdaş anlamda Taylor'un fikirleri büyük önem taşımaktadır. Birçok yöneticinin günümüzde de Taylor'un fikirlerine göre hareket ettiğini onu yaşattığını gözlemekteyiz. Bazı işçilerin günümüzde de sadece finansal ödüllerle motive olduğunu görüyoruz (Özkalp ve Kırel, 2001:14).

Klasik yönetim yaklaşımının ikinci önemli ismi Henri Fayol'dur. Fayol düşünceleriyle Taylor'un tamamlayıcısı olmuştur. Fayol, yönetim süreci yaklaşımında sadece "örgüt yönetimi" ile ilgili değil, yönetimin tüm süreçleri ve yönleri ile ilgili ilkeler geliştirmiştir.

Fayol'a göre yönetim faaliyetleri belirli bir süreç şeklinde gerçekleşir. Bu sürecin temel aşamaları (yönetim yazınında POCCC kısaltması); planlama, örgütlenme, emir komuta (yürütme), eşgüdüm ve kontrol şeklindedir. Akademik yazında "eğitim ve yetiştirme"nin de ayrı bir aşama olarak yönetim sürecine dahil edildiği görülmektedir (Peker, 1995:75). Fayol'a göre yönetim evrenseldir. Hem devlet hem de işletme yönetiminde vardır.

Amerika'lı yönetim bilimciler L.Gulick ve L.Urwick yönetim biliminin gelişmesine katkıda bulunmuşlardır. Gulick, yönetim süreçlerini Fayol'un POCCC formülüne benzeyen ve POSCORB olarak ifade edilen planlama, organizasyon, personel yönetimi, emir verme, koordinasyon, kontrol ve bütçeleme aşamaları ile formülize etmiştir (Tortop vd., 2000:19). 


\subsection{Bürokrasi Modeli ve Max Weber}

Weber'in yönetim bilimine katkısı "İdeal Bürokrasi" modeli ile olmuştur. Weber'e göre bürokrasi modern toplumun ayrılmaz bir parçasıdır. Weber'in ideal bürokrasisinin amacı etkin ve verimli hizmet sumaktır. Weber bürokrasisinin temel unsurları; hukuki çerçeve (mevzuat), hiyerarşi, iş bölümü, resmi belgeleme yönetimi, profesyonel yönetici sınıfın varlığı ve kariyer imkanı sunan memuriyet (istihdam) sistemidir (Tortop vd., 2000:19).

Klasik yaklaşımın temelinde "verimlilik" vardır. Yönetimde maddi güdülemeye öncelik vermişlerdir. Bu düşüncenin temelinde "ekonomik insan" varsayımı yatmaktadır. Klasik yaklaşımı geliştirenler; insanı üretimi artırmanın aracı olarak görmelerine karşın, yönetimi bilimsel olarak ele almış ve temel kavramları kazandırmışlardır.

\subsection{Neo-Klasik Yönetim Yaklaşımı}

Klasik anlayışın insana yeterli değeri vermemesi uygulamada önemli sorunlara yol açmış ve önemli eleştiriler almıştır. 1920'lerden sonra yönetim içerisindeki özellikle birey ve grup ilişkileri ile insan beklentileri incelenmeye başlandı. Yönetimin bu yeni yaklaşımı kendi içinde bir bütün oluşturmamasına karşın ortak olarak insan ve insan grupları arasındaki ilişkilere eğilmeleridir. Neo-klasik yönetim kuramı, klasik anlayışın eksik bıraktığı insan unsurunu incelemiş ve bu düşüncelere insan unsurunun eklenmesi gerektiği ileri sürülmüştür.

\subsection{Davranışçı Yaklaşım}

Davranışçı yaklaşıma göre işgörenlerin güdülenmesinde sadece maddi güdüleyiciler değil; onların sosyal ve psikolojik durumları da önemli rol oynar. İşgörenlerin belli bir sosyal gruba dahil olmaları, sosyal grubun üyeleri arasındaki ilişkiler ve yalnız olmamanın verdiği haz yani manevi tatmin de işgörenleri güdülemeye ve daha iyi çalışmaya yönlendirir.

Abraham Maslow ve İhtiyaç Hiyerarşisi: Maslow’a göre insan ihtiyaçları üç sınıfa ayrılır;

- Bedeni ihtiyaçlar (fizyolojik ihtiyaçlar)

- Sosyal ihtiyaçlar (güvenlik gereksinimleri, sevgi, ait olma, taktir ve saygi)

- Kendini gerçekleştirme (yaratıcılık)

İşgörenlerin bu ihtiyaçları karşılanırken; alt derecedeki ihtiyaçları karşılandıktan sonra üst derecedeki ihtiyaçlarının karşılanmasını isteyeceklerdir.

Davranışsal teorinin gelişmesine başta Elton Mayo, Abraham Maslow, Chester Bernard, Douglas Mc Gregor, Kurt Lewin, Fritz Roethlisberger, Rennis Likert ile Chris Argyris olmak üzere pek çok araştırmacının önemli katk1ları olmuştur (Peker, 1995:90).

\section{5. Çevresel Yaklaşım}

Devletin ekonomik ve sosyal yaşama müdahalesi ve kamu hizmetlerinin genişlemesi sonucu, yönetim biliminde çevre ilişkilerine önem verilmesi sonucunu doğurdu. Bir grup bilim adamı yönetimi sadece insandan hareketle değil çevre açısından da incelediler. Bunlar; demokratik yönetim, liderlik, halkla yönetim ilişkileri, uyum ve bürokrasi-çevre ilişkilerini ele aldılar. Klasik anlayışa tepki olarak doğan neo-klasik yaklaşım, insanı temel almıştır. Örgüt yönetiminin insani değerler esas alınarak yönetilmesi anlayışını getirmiştir. 


\section{6. Çağdaş Yaklaşımlar}

\subsubsection{Sistem Yaklaşımı}

Klasik yaklaşımda daha çok örgütün yapısına, neo-klasik yaklaşımda ise daha çok insana önem verilmiştir. Yönetim bir bütün olarak incelenmemişti.

Yönetimi örgüt düzeyinde kavramlaştıran ve örgüt genel sistem teorisi çerçevesinde bir toplumsal sistem olarak gören bütüncül yaklaşımlar, 1958 yılında J.G. March ve Herbert Simon'un “Organizations" Yönetim kitabının yayınlanması ile yönetim literatürüne girmeye başlamışlardır (Peker, 1995:23). Sistem yaklaşımıyla yönetim bir bütün olarak ele alınmış ve incelenmiştir. Simon'a göre, yönetimde insan davranışının temelinde karar verme süreci vardır.

Sistem yaklaşımının temelinde örgütsel karar ve davranışlar, örgüt içi ve dışı birçok etkenin karşılıklı olarak etkileşimini esas alarak ortaya konulmalıdır. $O$ halde yöneticinin örgüt içi ve örgüt dışı unsurlar arasındaki ilişkileri anlaması, karar vermesi ve eylemde bulunması süreçlerinde bu ilkeyi esas alarak hareket etmesi gerekir (Eren, 2001:54). Sistem yaklaşımına göre, gruplar, insanlar ve yöneticiler sistemin bir parçasıdır. Örgüt içinde oluşturulan bütün sistemlerin görevleri iyi belirlenmelidir.

\subsubsection{Durumsallık Yaklașımı}

Durumsallık yaklaşımı ile ilgili; Burns ve Stalker, Lawrance ve Lorsch, James Thompson gibi düşünürler araştırma yapmışlardır. Durumsallık yaklaşımına göre hiçbir model bir örgüt için tam uygun olmayabilir. Yönetici başında olduğu örgüte uygun modeli uygulamalıdır. Yöneticiler değişime ayak uydurmalı, kurallarını esnek tutarak modellerini yeri geldikçe değiştirebilmelidirler.

Her örgüt bir örnek olaydır ve yöneticileri tarafından örgüt içi ve çevresel faktörlerin başarıyı etkileyen kural ve ilkeleri ortaya çıkarılmalıdır (Eren, 2001:57).

\section{YEREL YÖNETIMLER: KAVRAM VE KURAMSAL YAKLAŞIMLAR}

Kamu yönetimi sisteminde üç tip kamu tüzel kişisi bulunmaktadır: Devlet, yerel yönetimler ve kamu kurumları. Geniş anlamda devlet, yukarıda zikredilen üç tip kamu tüzel kişisinin tamamını ifade etmek için de kullanılmaktadır. Dar anlamda devlet ise sadece devletin tüzel kişiliğini ifade etmektedir. Yerinden yönetim olgusu modern devlet yapısının bir ürünüdür. Kamu gücünü alan ve işlev olarak genişlemesi modern devletin yönetim cihazının dikey ve yatay boyutlarda değişime uğramasına yol açmış, uygulamada yerinden yönetim modern devletin kaçınılmaz unsuru olmuştur (Öztekin, 2002:287).

Yerel yönetimler; kent, köy, belediye gibi belirli bir coğrafik alanda ikamet eden yerel halka, birlikte yaşadıkları yerel coğrafya ile ilgili yerel ve ortak nitelikteki kamu hizmetlerinin sunulması amacıyla anayasa ve/veya kanunla görev ve yetkileri belirlenmiş, karar organları (bazen de yürütme organları da dahil) yerel halk tarafindan seçimle göreve getirilen, idari ve mali özerkliğe sahip, kamu gücü ile donatılmış, tüzel kişileridir.

Yerel yönetimler bütün ülkelerde tarihsel gelişim süreçleri içerisinde devletle beraber ortaya çıkmıştır. Ülkelerin tamamında kamu yönetiminin önemli ve vazgeçilmez bir parçası olarak gelişen yerel yönetimler devletin tamamlayıcı bir parçası olarak yerel hizmetleri sunmaları ve yürütmeleri gelenek haline gelmiştir. Yerel yönetimlerin uygulama alanı günümüzde de giderek genişlemekte ve yerel yönetimler buna paralel olarak önem kazanmaktadır.

Ülkelerin bütününde yerel yönetimler, kamu yönetiminin temel, asli, önemli ve vazgeçilmez bir unsuru olarak kabul edilir. Günümüzde bir ülkedeki yerel yönetimlerin etkinliği ve gücü, demokrasinin o ülkedeki gelişimi ve geldiği seviye ile de yakından ilişkilidir. Yerel hizmetlerin etkin ve verimli bir şekilde hayata geçirilmesi açısından son derece önemli olan yerel yönetimler, katılım kültürü ve demokrasi açısından da son derece önemli, vazgeçilmez kurumlardır (Eryılmaz, 2007:132).

Yerel yönetimler deyimini karşılamak üzere "mahalli idareler" sıkça kullanılmaktadır. İlk olarak Jeremy Bentham tarafindan İngiltere'de kullanılan "local government" deyimi Türkçe'de yerel yönetimler olarak tercüme edilmektedir. "Government" terimi, birebir çeviriyle "hükümet" anlamına gelir ki bu da yerel yönetimlerin adeta yerel hükümetler olarak görüldüğünü anlatır. Başka bir ifadeyle, yerel yönetimlerin diğer idari birimlerden ayrı olduğunu ifade etmek için "local government" tabiri kullanılır ve yerel yönetimler, yerel ölçekte bir hükümet olarak düşünülerek hükümet niteliğinde fonksiyon icra eden kuruluşlar olarak 
düzenlenmeye çalışılır (Ulusoy ve Akdemir, 2010:121). Oysa "mahalli idare" kavramının İngilizce karşılığı "local administration'dır. Mahalli idare deyimi, bu kuruluşların demokratik niteliğinden çok idari/hukuki yönünü vurgulamaktadır.

Yerel topluluğun ihtiyaç duyduğu kamusal mal ve hizmetleri karş1layan, seçimle yönetime gelen yerel yönetimler ve demokrasi en çok bir arada kullanılan kavramlardır (Pustu, 2005:121). "John Start Mill ve Alexis de Tocgueville gibi düşünürler yerel yönetimleri yalnızca yerel topluluklara kamu hizmeti sunan birimler olarak değil, “demokrasinin ilkokulu” olarak algılamışlardır” (Keleş, 2011:13).

Demokrasi, yalnızca "ülkeyi kim yönetmeli" sorusuna cevap arayan ve halkın sandık başında sadece oy verdiği bir sistem değildir. Demokratik sistemin esası halkın yönetime katılması, bu amaçlarla oluşturulan organlarda yer alması yöneticilerini etkilemesi ve denetlemesidir (Ery1lmaz, 2011:149).

Yerel yönetimler yerel topluluğa en yakın birimlerdir. Yerel topluluğu en yakından ilgilendiren kararlar yerel yönetim birimlerince alınır. İlgili coğrafi alanda yaşayan yerel topluluk bireylerinin yerel yönetime ilgileri, katılımı, katkı ve yardımları onları güçlendirmekte en önemli etkenlerin başında gelir (Tortop vd, 2008:35).

Katılım; bireylerin kamu politikalarının belirlenmesi, uygulanması, denetlenmesi ve revize edilmesi süreçlerinde yer almasını sağlar. Katılım, bu süreci sağlayacak mekanizmaları da yasal güvence altına alarak dinamik bir etkileşim oluşturur. Katılımcı demokrasi herkesin bu siyasal sürece devamlı ve olabilecek her biçimde katılmasını talep etmektedir (Parlak ve Ökmen, 2010:340).

Yerel katılım olmadan yerel yönetimler kamu hizmeti üreten sıradan bürokratik kuruluşlar olmaktan öteye gidemez. Demokratik katılım kanallarının ve hesap verebilirlik mekanizmalarının güçlendirilmesi, aynı zamanda yerel yönetimleri de güçlendirecek, demokrasinin gelişimi yönünde katkı sağlayacaktır (Canpolat, 2010:58).

İnsanların birlikte yaşamaları neticesinde ortaya çıkardıkları sosyal organizasyonlar tarih boyunca çeşitli isimler altında gelişmiştir. Bunlar kabile, boy, klan, aşiret, köy, mezra, kasaba, site, kent, polis, komün, eyalet, kanton, kent devleti gibi yönetsel birimlerden devletlere (krallık, hanlık, mutlak devlet, ulus devlet gibi) kadar geniş bir spektrumdan oluşmaktadır. Çin'de tarihsel olarak M.Ö. 2000'li yıllarda kurulmuş krallıklar mevcutken, Hindistan'da kentler idari anlamda yerel özerkliklerini uzun süre korumuşlardır. Aynı dönemde Mısır ile sonrasında Asurlular, Babil ve Yunanlılarda da bir yönetsel yapı olarak "site"ler görülmüştür.

Yerel yönetimlerin tarihi Orta Çağ’a uzanmaktadır. Bu dönemde belirli bir coğrafi alan üzerinde yaşayan birlikte yaşamaktan doğan ihtiyaçları karşılayan "komün" denilen birliktelikler ya da örgütlü birlikler bulunmaktadır. Yerel yönetim geleneğinin tarihi de bu "komün"lere dayanmaktadır. Yerel yönetim, "hukuksalsiyasal" bir kavram ve "yönetsel-sosyal" bir kurum olarak Avrupa'da Orta Çağ sonlarına kadar komün şeklinde varlığını sürdürmüştür. Burjuvazi desteğinde merkezi devleti esas alan "Modern devlet" olgusuna geçilmesiyle beraber komünlerin siyasal ve yerel özgürlükleri, yönetsellikleri merkezi devlete ve belediye kurumlarına devredilmiştir (Erkul, 2010:11).

Araştırma kapsamında yapılan literatür araştırması sırasında yerinden yönetim, adem-i merkeziyet, decentralisation, decentralization terimleriyle aynı anlamda kullanıldıkları fark edildiğinden, bu konuda bir açıklamaya ihtiyaç görülmüştür.

Kamu yönetimi sözlüğüne göre yerinden yönetim; yönetsel nitelikteki kararların alınması ve bu kararlara esas görevlerin icra edilmesinde yetki ve sorumluluğunun merkezi idare dişında kalan, hizmet yerinde bulunan idare ve kurumlarca yerine getirilmesi durumu olarak tanımlanmaktadır. Yerinden yönetim kavramının eski terimde adem-i merkeziyet, Fransizcada decentralisation, İngilizcede ise decentralization kelimelerine karş11k gelmektedir (Bozkurt ve Ergun, 1998:260). Sosyal bilimler sözlüğüne göre yerinden yönetim; merkeziyetçiliğin (merkezden yönetimin) tam tersi olarak yerel yönetimlerin merkezi yönetim karşısındaki görev, yetki, sorumluluk ve özerkliğinin genişletilmesi, merkezi idarenin gücünün kırılması, merkezi idareye ait örev ve yetkilerin merkez ile yerel arasında paylaştırılması, mutlak merkezileşmenin önlenmesine esas alınan karar ve uygulamalar olarak tanımlanmaktadır. Bu kavramın eski dilde adem-i merkeziyet, İngilizcede decentralization olarak karş1lık gördügü belirtilmektedir (Demir ve Acar, 1997:241-245). Kentbilim terimleri sözlügünde de yerinden yönetimi; yürütme erkinin belirli ölçülerle merkezi yönetim ve yerel yönetim birimleri arasında paylaştırılması ve bir kısım yetkilerin yerel yönetimler eliyle kullanılmasını gerektiren yönetim anlayışıdır. Bu kavramın eski dilde mahalli idare - adem-i merkeziyet, Almancada decentralisation, Fransızcada administration locale, decentralisation, İngilizcede decentralization, local government olarak karş1l1k görmektedir (Keleş, 1980:145). Türkçe sözlükte ise yerinden yönetim; merkezi yönetimin kimi yetkilerinin yerel yönetimlerce kullanılmasına dayanan yönetim biçimi olarak tanımlanmaktadır (Püsküllüoğlı, 1995:1640). 
Yerel yönetim terimleri sözlüğünde; adem-i merkeziyet, bir devlet hizmetinin merkezi birim eline değil, yerel(mahalli) muhtar bir kuruluşa verilmesi olarak tanımlanmakta ve bu sistemin merkeziyetçiliğin karşııtı olduğu, merkeze ait bazı görevlerin merkeze karşı kısmen bağımsız, kısmen merkezin denetimine uyruk yerel yönetim katları eliyle getirilmesi olarak tanımlanmaktadır (Üstün, 1999:3,220).

Reform sözcüğü Azerbaycan'da yerel yönetimlerle ilgili olarak en sik duyulan kavramlardan birisidir. Yerel yönetimler, tüm ülkelerde kamu yönetiminin vazgeçilmez, önemli ve tamamlayıcı unsurunu oluşturmaktadırlar. Bir ülkedeki yerel yönetimlerin etkinliği ve gücü, o ülkenin demokrasisinin düzeyi ile de yakından ilişkili olmaktadır. Günümüzde yerel yönetimlere, yerel düzeyde demokrasinin gelişmesinin bir aracı olarak da bakılmaktadır. Günümüzde bütün dünyada yerel yönetimler giderek daha çok önem kazanmaya başlamışlardır. Kentleşme ve şehirlerin büyümesiyle birlikte kentlerin nüfusu kalabalıklaşmış, hizmetlere olan taleplerde ise büyük artışlar meydana gelmiştir. Merkezi yönetimin bu hizmetleri var olan yapısıyla yerine getirmesinin de mümkün olmadığ 1 görülmektedir.

Genel olarak yerel yönetimler, belli bir coğrafi alanda (yerde) yaşayan yerel halka kendilerini en çok ilgilendiren yerel konularda hizmet üretmek amacıyle, anayasa ile kurulan, karar organları (ve bazen yürütme organları da) kendisini oluşturan yerel halk (seçmen) tarafından seçilen, yasa normları ile açıkça belirlenmiş yetkilere, görevlere, bütçeye, özel gelire ve personele sahip olan, görevi olan kamu hizmetlerini gerçekleştirebilmek için merkezi idareden ayrı olarak kendi teşkilat yapılarını kurabilen, özerk kamu tüzel kişileridir (Yalçındağ, 1995:21).

Yerel yönetimlere kamu yararı doğrultusunda etkililik ve verimlilik üretme yanında demokrasi okulu olma işlevi de yükletilmektedir. Yerel yönetimlerin coğrafi olarak yakınlığı nedeniyle halk katılımı açısından uygun olduğu kuramsal olarak kabul edilmektedir. Yerel yönetimler denildiğinde yerel bir topluluktaki bireylerin ortak nitelikteki ihtiyaçları olan kamu mal ve hizmetlerini sağlayan, yerel topluluğun kendi içerisinden seçtiği kişilerden oluşan organlarca yönetilen organizasyonlar anlaşılmaktadır (Tekeli, 1983:3).

Yerel yönetimler; merkezi idarenin haricinde, yerel nitelikteki bir topluluğun ortak ihtiyaçlarını gidermek maksadıyla kurulan, karar organları doğrudan doğruya halk tarafından seçilen, özerk ve demokratik bir yönetim kademesi, kamusal bir örgütlenme olarak da tanımlanabilir (Bozkurt ve Ergun, 1998:258).

Genel kabul gören bir tanıma göre yerel yönetimler; bir yerel topluluk tarafından seçilen kişilerce yönetilen, kamu tüzel kişiliğine sahip, özerk veya bağımsız konumu ve kendisine ait bir bütçesi bulunan yönetsel bir birimdir (Güler, 1997:75). Tüm bu tanımlardan yerel yönetimlerin özelliklerini şu şekilde maddeleştirebiliriz:

- Belli bir coğrafi alanla sınırlı olmalıdır,

- Yerel bir topluluğun gereksinmelerine uygun kamu mal ve hizmetleri sağlamalıdır,

- Halkın seçtiği organlarca yönetilmelidir,

- Merkezi yönetimden ayrı bir maliyesi ve örgütlenmesi bulunmalıdır.

\subsection{Temsil Kavramı}

Demokrasi kuramı ortaya atılırken insanların ne istediklerini, gereksinmelerinin ne olduğunu bildikleri varsayımından yola çıkılmıştır. Totaliter rejim kuramcıları ise insanlarda bu "bilme"nin varolmadığını öne sürmüşlerdir. İki yaklaşım arasındaki bu temel farklılık, temsilin belirleyici etkisini ortaya koymaktadır (Şaylan, 1998). Hukukta temsil, temsilcinin, temsil ettiği kişinin nam ve hesabına aldığı yetki çerçevesinde hareket etmesi demektir.

Siyasette temsil, "bazı kişilerin diğerleri adına hareket ettiği düzenlemeler" anlamına gelir (Miller vd., 1995:359). Bir başka tanıma göre temsil, "temsilcinin yapmış olduğu faaliyetler dolayısıyla hesap verebilirliği aracılığıyla söz konusu olan bir ilişkidir", üçüncü bir tanım olarak "ilişkinin içeriğinin başkası için faaliyette bulunma olmayıp, temsil edilenin yerine geçme, simgeleme, örneğin cumhurbaşkanının bir ulusu temsil etmesi” anlamındadır, dördüncü tanım temsili "bir bireyin veya grubun temsili olmayıp, belirli bir çıkarın korunması, örneğin çalışma koşullarının iyileştirilmesi için faaliyette bulunanın, bu çıkarlara sahip olanları temsili” olarak görür (Kalayc1oğlu, 1984:376). 


\subsubsection{Temsil Düşüncesinin Tarihi Gelişimi}

Temsil bugünkü anlamıyla köklerini ortaçağda bulmaktadır. Roma İmparatorluğunun çökmesi ile Avrupa'da oluşan otorite boşluğu feodal senyörlerin egemenliğini getirmiş, kurulan devletler senyörler üzerinde merkezi otoritenin etkisini hissettirememişlerdir. İşte bu dönemde kral yeni vergiler koymak gibi bazı kararlarını uygulayabilmek için tebaanın rızasını almak zorunda kalmış bu da senyörlerin temsilcilerinden oluşan bir meclisi gerekli kılmıştır.

Temsil düşüncesi ortaçağda belirmeye başlamakla birlikte, demokrasi ilkçağlardan bu yana özellikle yunan sitelerinde uygulanmıştır. Demokrasi bir siyasal sistem olarak ilk kez Antik Yunan'da ortaya çıkmış ve site yurttaşlarınca doğrudan demokrasi olarak yaşama geçirilmiştir. Yunanlı yurttaş -kadınlar, köleler ve yabancılar dışında- yasaların yapılmasına doğrudan doğruya katılır, kura ya da sırası gelince yönetici olurdu.

Eski Yunan Demokrasi genel olarak doğrudan bir azınlık demokrasisi şeklinde kendisini göstermektedir. Kurulan meclise tüm vatandaşların katılması, bir halk mahkemesi olması, kısa süreliğine kura ile belirlenen kamu görevinin olması ve ilgili görevin uzun bir süre ücretsiz olması gibi muhtelif özellikler bu genel çerçevenin ilginç ayrıntılarıdır (Kışlalı, 1984:68). Vatandaşlar arasında ekonomik eşitsizlik olmakla birlikte, siyasi eşitlik sağlanmıştır.

Atinalı her erkek vatandaş ekonomik gücü ne olursa olsun yönetime doğrudan doğruya katılabilmiş ve bugün kimi yazarlarca idealleştirilen doğrudan demokrasinin halk tarafından uygulaması yapılmıştır. Ancak Atinalı yurttaş (yönetime katılma hakkı olan yani yabanc1, köle ve kadın olmayan) geçinmek ve üretmek için ilkel üretim araçlarını kullanma zorunluluğu duymayan ve zamanını yönetime ayırabilen kişidir. Bu yapı nedeniyle de siyasal katılım en üst noktada gerçekleşebilmiştir. Bu doğrudan ve kitlesel katılımın övgüye değer olduğuna kuşku yoktur ancak idealsize ederek abartıya kaçmamak gerekmektedir (Şaylan, 1998:19). Yunan Site Devletlerinde uygulanan doğrudan demokrasi bizde uygulanmamıştır, bizim demokrasimiz temsilciler yoluyla oluşan Temsili demokrasidir. Bazı Yunan şehirlerinin bir araya gelip (öncelikle ortak savunma amacıyla) ittifaklar, birlikler ve konfederasyonlar gibi yetersiz temsil hükümetleri kurmuş olmalarına rağmen bu temsil sistemleri hakkında çok az şey bilinmektedir. Demokratik düşünceler ve uygulamalar ile daha sonraki temsili demokrasi biçimi üzerinde aslında hiçbir etki bırakmamışlardır (Dahl, 2001:12).

\subsection{Yerel Yönetimler ve Demokrasi}

Liberal yaklaşıma göre "Yerel Yönetim Kuramı" özgürlük, demokrasi, etkinlik ilkelerine dayandırılmış olup gücünü yüzyıllardır devam ede gelen gelenekten almaktadır (Dahl, 2001:12). Bazı yayınlarda yerel yönetimlerin varlık nedenleri, bazılarında yerel yönetimlerin amaçları, ve kimilerinde de yerel yönetimlerin varlık nedenleri arasinda sayılan Kurama göre;

Yerel yönetim birimleri üç amacın varlığını gerçekleştirmektedir (Tekelitekeli, 1983:3);

1. İnsanların toplu olarak gereksinimlerini karşılayabilmek amacıyla kurulmuş; bu amacı gerçekleştirebilmek için de sunduğu kamu mal ve hizmetlerinin üretiminde ve/veya tüketiminde bağımsız olmalarıdır.

2. Devletin toplumsal yapıda gerçekleştireceği kamu hizmetlerinin tamamının sadece merkezi yönetimce üretilmesi yüksek maliyetli olacağı için kamu hizmetlerinde etkinlik esas alınarak bu konuda merkezi idare ile yerel idareler arasında bir iş ve görev bölümü yapılmalıdır.

3. Yerel yönetimlerin varlığı sadece teknik bir iş bölümü olarak değerlendirilmemelidir. Demokrasi, yerel yönetimlerin varlık amacı ve anlayışı içinde gerçekleştirilmek istenen üçüncü bir amaç olarak esas alınmalidır.

Yerel yönetim kuramında ortaya konan anahtar sözcükler: etkinlik, sorumluluk, şeffaflık, demokrasi ve yönetilenlerin karar süreçlerine katılımıdır (Sekizinci (Beş Yıllık Kalkınma Planı, 2001:15).

Sonuç olarak yerel yönetimlere ilişkin tartışmaların giderek daha büyük ölçüde demokrasi ve demokratik değerler çevresinde yapıldığını görmekteyiz (Çitci, 1989:18). Özellikle kuramın ortaya koyduğu ilkeleri belirledikten sonra uygulamada görülen sorunları ve sonuçları tespit ederek kuramın geçerliliğini tartışmak gerekmektedir. 


\subsubsection{Yerel Yönetimler ve Demokrasi: Liberal Kuram}

Kavramsal açıdan demokrasi; Lincoln'ün ünlü deyişiyle, "halkın, halk için, halk tarafindan yönetimi" olarak tanımlanmaktadır. Yerel yönetimlerin genel olarak tanımları ve tarihsel nitelikleri gereği demokratik katılım ve denetime daha çok olanak sağladığı ileri sürülmekte, büyük ölçekli yönetimlerin merkezi planlama ve uygulama, ekonomik ve yönetsel etkililik için elverişli olmakla birlikte demokratik denetimi zorlaştırdığı kabul edilmektedir (Eke, 1985:45). Halkı, günlük yaşantısı içerisinde çok yakından ilgilendiren ve etkileyen kamu hizmetleri ile bağlantısı kopmakta ve bu hizmetler ile ilgili kararlar, bu hizmetlerden doğrudan doğruya etkilenen insanların uzağında oluşmaktadır (Kaya, 1992:8). Denilerek merkezi yönetimin sakıncaları anlatılmaktadır.

Artık bir özdeyiş haline gelen temel yargılardan birisi de yerel yönetimlerin demokrasinin okulu ya da beşiği olduğudur (Çitçi, 1989:18). Bunun nedeni, yerel yönetimler aracılığı ile yönetime doğrudan katılıma olanağının bulunmasıdır (Sekizinci Beş Yıllık Kalkınma Planı :113). Katılım süreci ile yerel toplulukların mensubu oldukları yerel yönetimlerin kararlarını etkileme imkanı ortaya çıkmıştır. Buradan hareketle de katılım sürecinin, yerel idareler üzerindeki halk denetimini de arttırarak, yerel demokrasiye gerçek niteliğini kazandıracağı ileri sürülmektedir (Kaya, 1992:3).

Yerel yönetimin vatandaşlara demokratik ilke ve davranış alışkanlığı kazandırdığı "demokratik terbiye kuruluşları" olduğu, yerel konuları olgun insan davranışları çerçevesinde tartışan ve birbirine saygıll, en iyi yöneticileri seçen kişilerin ulusal düzeyde de aynı davranış içinde bulunabileceği, yerel düzeyde başarılı olunabilirse, ülke düzeyinde de başarılı olunacağı ileri sürülmektedir (Tortop, 1994:34).

Yerel yönetimlerin temelinde yerel demokrasi değerlerinin bulunduğu kabul edilir. Bu değerler yerel halkın kendilerini yakından ve en çok ilgilendiren (müşterek) konularda özgürce ve kanunlarda belirtilen demokratik yöntemler ile kendi kendilerini yönetmelerini öngörmektedir (Yalçındağ, 1995:21). Yerel düzeyde halkın kendi kendisini yönetmesine olanak verecek en etkili ve kurumsal yol yerel yönetimlerin güçlendirilmesidir. Bu bağlamda yerel topluluklar için doğrudan ve müşterek (ortak) nitelikteki hizmetler noktasında kendi kendilerini yönetmelerine imkan sağlanması gerekmektedir (Yalçındağ, 1999:107).

Mill ve Tocqueville, yerel yönetimleri toplumlar için bir siyasal eğitim aracı olarak kabul etmişlerdir. Dolayısıyla bu yönetimlerin görmekte oldukları hizmetler ne olursa olsun bizzat demokrasinin temel öğesi olduğunu savunmuşlardır. Keith Panther Brick, yerel ölçekte toplum demokratik bir şekilde yönetilmiyorsa o halkın içinde bulunduğu ülkenin demokratik olduğunun da ileri sürülemiyeceğini belirtmiştir. Fabian Sosyalistlerinden Sidney Webb, yeni bir sosyalizm yolu olarak "belediye sosyalizmini" önermiştir. Sidney ve Beatrice Webb'ler "bu hizmetlerin (kamu hizmetleri) sunulması görevi olabildiği ölçüde az bir merkezi gözetim altında yerel yönetimlere bırakılmalıdır", demektedirler. W.J. Mc Kenzie, çağdaş yerel yönetim düşüncesinin dayandığı değerleri aşağıdaki şekilde tanımlamaktadır;

- Yerel yönetimler toplumların geleneksel haklarını ortaya koyan idarelerdir.

- Yerel nitelikteki bir kısım kamu hizmetlerinin uygun, verimli ve etkin bir şekilde halka sunulması yöntemidir.

- Toplumun siyasal eğitiminin bir aracı olduğu için yerel yönetimler, ayrıca değer taşımaktadır.

Avrupa Konseyi de yerel ve bölgesel yönetimlerin demokrasinin temeli olduğu görüşünü savunmakta ve "komünler devletin temelini oluşturur" demektedir (Keleş, 1992:51). Montesquieu Kanunların Ruhu adlı yapıtında kentlerin ayrıcalıklarını krala bırakmalarıyla toplumda mutlakıyetin kurulmasının sakıncalarına değinerek ideal devleti yerel toplulukların yaratabileceğini savunur (Tekeli, 1983:3).

Yerel yönetim kuramında, yerel yönetimlere, sınırlı coğrafi alanları nedeniyle halk katılımının daha yüksek olacağına dair genel kabullerden ileri gelen, demokrasinin beşiği olma ve demokrasi eğitimi verme işlevi yükletilmektedir. Kuram, yerel yönetimlerin kendiliğinden, yapısı gereği demokratik olduğu, merkezi yönetime göre etkili ve verimli olduğu, görülen aksaklıkların yanlış uygulamadan kaynaklandığ 1 varsayımına dayanmaktadır. 


\subsubsection{Yerel Yönetimler ve Demokrasi İlişkisi}

Yasal düzenlemelerde de yerel yönetimlere halk katılımını sağlayacak hükümler konulmuştur. Uluslar arası sözleşmelerde de halk katılımı her zaman öne çıkarılmış, yerel yönetimlerin özünü oluşturduğu iddia edilmiştir.

Avrupa Yerel Yönetimler Özerklik Şartının önsözünde "vatandaşların kamu işlerinin sevk ve idaresine katılma hakkının Avrupa Konseyine üye devletlerin paylaştı̆̆ demokratik bir ilke olduğu ve bu hakların en doğrudan kullanım alanının yerel düzeyde olduğu" belirtilmiștir. Aynı șartın önsözünde "yerel makamların her türlü demokratik rejimin esaslı temellerinden biri" olduğu kabul edilmektedir (Mengi, 1998:69).

\subsubsection{Adem-i Merkeziyet}

Adem-i merkeziyet (Decentralization, Yerinden Yönetim) kavramı Kamu Yönetimi Sözlüğü’nde; kamu hizmetlerin gerçekleştirilmesine esas olarak yönetsel kararların alınması ve bu kararların hayata geçirilmesinde gerekli olan görev, yetki ve sorumlulukların işlevsel (fonksiyonel) veya coğrafi (yer) ölçütlere bağlı olarak merkezi idare dışında mevcut olan yerinden yönetim birimlerince üstlenilmesi durumu olarak tanımlanmaktadır (TODAİE, 1998:260).

Dünya Bankası, 1999/2000 Dünya Gelişme Raporunda adem-i merkeziyetçilik (decentralization), merkezi hükümetin sahip olduğu siyasal, ekonomik ve idari güçlerin yerel birimlere (subnational units) aktarılması biçiminde tanımlanmaktadır. Dünya Bankası bir yönetimin; adem-i merkeziyetçi sayılması için, bazı politika alanlarında bağlayıcı kararlar alma yeterliliğine sahip olan, seçilmiş, özerk yönetimler içermesi gerektiğini belirtmektedir (Decentralization:Rethinking Government, 1999:108).

Kamu yönetimi sözlüğünde, kavramın başlıca iki öbekte ele alınabileceği belirtilmektedir. Bunlar;

- Hizmet yönünden yerinden yönetim kuruluşlarını ve onlarca yürütülen hizmetleri belirten hizmet adem-i merkeziyeti

- Coğrafi olarak merkez dışındaki yönetsel kuruluşlarca yürütülen hizmetleri belirten coğrafi adem-i merkeziyettir.

Hizmet yönünden yerinden yönetim kuruluşları, diğer hizmetlerden ayrılabilen ve sınırlanabilen bir kamusal hizmetin gerçekleştirilmesinde bu hizmetin nitelik olarak merkezi idarenin hiyerarşik yapısı içerisine alınmasının etkin/verimli olmayışı, hizmetin içeriği ve teknik niteliği ile yerine getirilmesinde belirli bir özerklik ihtiyacının bulunması nedeniyle (işlevsel ölçüt) coğrafi konumu dikkate alınmaksızın merkezi yönetimin dışında bulunan kurumlardır.

Coğrafi ölçütlere göre örgütleniş dar anlamıyla yerinden yönetim, (decentralization) kavramı merkezden yönetimin karşıtı bir anlam içerir.

Yetki Genişliği (Deconcentration, Delegation): Merkezdeki kuruluşlar, merkezden uzakta bulunan bir örgüte, belli işlevleri yerine getirmelerine yetecek bir ya da daha çok yetkiyi, kendi adlarına kullanmak üzere devrederler. Merkezi idarelerin kimi etkinliklerini, taşrada oluşturdukları örgütler eliyle yürütmeleri, yetki genişliğine dayanan bir uygulamadır. Yetki genişliğinin temelinde, merkezden yönetim sonucunda doğan bazı sakıncaları gidermek maksadıyla, merkezi yönetimin denetimi altındaki bazı birimlere bazı yetkilerin devredilmesi yer almaktadır.

Yerinden Yönetim (Devolution): Yerinden yönetim; yasalar gereği oluşturulmuş yönetim organlarının, merkezi yönetimin üstlendiği görevlerden başka işlevleri yerine getirebilmeleri için, tüzel, siyasal ve akçal bir takım yetkilerle donatılmasıdır (Keleş, 1992:11).

Dünya Bankası adem-i merkeziyet kavramına, özelleştirme (privatization) -sorumluluğun kamu sektöründen tamamen uzaklaştırılması- biçiminde bir anlam daha yüklemektedir (Decentralization:Rethinking Government., 1999:108).

\subsubsection{Subsidiarite}

Subsidiarite kavramı Türkçe'ye "hizmette halka yakınlık" şeklinde çevrilmiştir. Ancak çeviri ile bu kavrama ölçüsüz bir şekilde birtakım anlamlar yüklenmiştir. Esasen subsidiarite kavramı anlam olarak ademimerkeziyetçilik ilkesini karşılamaktadır. Yönetim bilimi açısından merkeziyetçilik ilkesi; devlet (merkezi idare) teşkilatlanmasında yönetimin bütünlüğü esas alınarak organizasyon ve kademeleri arasında yukarıdan aşağıya (üstten alta/asta) gerçekleştirilen yetki devri ve işbölümünü ifade eder. Subsidiarite ya da ademi-merkeziyetçilik 
ilkesi ise organizasyon ve kademeleri arasında aşağıdan (asttan) yukarıya doğru görevler ayrımına göre yapılmış işbölümünü ortaya koymaktadır.

Ademi merkeziyetçilik ya da subsidiarite ilkesinde yetki devri söz konusu değildir. Bu ilkeye göre görev paylaşımında görevi üstlenen kademe, görevin gerektirdiği tüm yetkiyi de kendiliğinden elde eder. Avrupa Birliğine entegre olma çalışmaları kapsamında her geçen gün giderek genişleyen taleplerin net bir şekilde anlaşılması gerekir. Bu sebeple öncelikle de yönetimle ilgili ortaya çıkan hatalı kavramların giderilmesi, mevcut kapsamı içerisinde bırakılarak büyük bir kavram temizliği seferberliğine girişilmesi zorunlu hal almıştır.

Subsidiarite (ademi merkeziyet) ilkesini şu ana dek tarihin hiç bilmediği yepyeni bir kavram/ilke olarak değerlendirmenin hiçbir mantıklı izahı bulunmamaktadır. Bir devlet teşkilatlanmasında öncelikli ve esas olan merkezileşmiş (özellikle son 4 yüzyılın çağdaş modeli olarak) devlet yapılanmasıdır. Dünya geneline yayılmış olan bu yapılar ya üniter ya da federal biir devlet örgütlenmesi şeklindedir. Her iki yönetim türünde de merkezden yönetim ile yerinden yönetim modelleri beraber uygulamaktadır. Fakat bu modellerin idari teşkilatlanmaları aynı anda hem merkeziyetçiliği ve hem de ademi-merkeziyetçiliği temsil etmez. Hangisi daha ağır basıyorsa o tarafi ön plana çıkarır. Örneğin federal devlet olarak yönetilmekte olan bir ülkede merkezden yönetim kuruluşları daha ağır basarsa (ön plana çıkarsa) bu ülkedeki temel yönetim ilkesi merkeziyetçiliktir. Bununla birlikte bir üniter devlet modelinde yerinden yönetim kuruluşları yönetim mekanizmasında daha ağır basarsa (ön plana çıkıyorsa) bu ülkedeki temel ilke ademi merkeziyetçiliğe doğru değişir. Başka bir ifadeyle her iki ilke birlikte uygulanmasına rağmen, bu ilkelerden birisi yönetim yapısında diğerine göre daha baskın yani ön planda olmaktadır. Günümüzde Avrupa Birliği ve Dünya Bankası açısından temel sorun, devletlerin teşkilatlanmalarında merkeziyetçilik ilkesinden vazgeçmeleri üzerinedir. GÜLER (http://www.bes.org.tr/yorum/yenidenyapilanma.htm), devletin yeniden yapılanmasında karşı karşıya kalınan gelişmelerden birisinin de yerelleşme politikası olduğunu ifade etmektedir.

\subsubsection{Yerel Yönetimlere Ekonomik Bakış: Neo-Klasik Yaklaşım}

Teorik açıdan yerel yönetimlere ekonomik bir yaklaşımı ifade den bu açıklamalar, uygulamada yerel yönetimin türü ve sınırları, ekonomik faktörlerden daha çok sosyo-politik faktörlere göre belirlendiği için, önemli değilmiş gibi görünse de yerel yönetimlerin ekonomik mantığını ve arka planını kavramak açısından çok önemlidir.

Buradaki ekonomik ve sosyo-politik belirleme faktörleri ne kadar kesişirse başta kalkınma olmak üzere, kamudan özele kaynak aktarımı, kaynakların toplum kesimleri arasında yeniden bölüşümüne müdahale gibi konularda etkinlik ve verimlilik o kadar artacaktır. Bu ise yerel yönetimin temel değerleri ve ana fonksiyonları ile doğrudan ilgilidir (Ökmen, 2015:7).

\subsubsection{Yerel Yönetimlere Siyasal Yaklaşım: Liberal Açıklamalar, Neo- Liberal Yaklaşımlar ve Yerel Yönetim}

Yerel siyaset açısından temsil; içerisinde yer aldığı halk için düşünen küçük bir kesimin ve yine içinde yaşadığ1 halk adına kararlar almasıdır. Bu bağlamda yerel siyasette etkin bir katılım ile paydaş olan herkesin (çalışanlar, yönetenler, yerel halk) motivasyonu sağlanmaktadır. 1980 yılı sonrasında yerel yönetimler neo-liberal ekonomi politikaları, küreselleşme ve yeni kamu yönetimi (işletmeciliği) anlayışları sonrasında önemini ve etkisini arttırmış yönetsel idarelerdir.

Yerel siyaset sözcüğ̈̈; herkesin üzerinde uzlaşı sağladığı, genel kabul görmüş, içeriği, çerçevesi ve sınırları kesin olarak belirlenmiş bir tanımlama olmaktan ziyade, birçok farklı bakış açısından ele alınarak, çok yönlü anlamlar yüklenen bir kavramdır. Kavram, genel olarak kanunda belirlenen usullere göre seçim ile yerel görevler kapsamındaki siyasal etkileşim olarak ifade edilmektedir (Alkan ve Çiftçioğlu, 2007:2). Buradan hareketle yerel siyaset sadece yerel yönetim birimlerini değil, aynı zamanda bu birimler dışında kalan diğer yerel kurum ve aktörler ile etkileşimlerini kapsayan süreçleri de içine alır. Yerel siyaset ile ilgili temel kavramlar, doğrudan kent ve kent yönetimi ile ilgilidir. Çünkü kentler, içinde bulunduğumuz modern dönemde toplumsal ilişkileri ve etkileşimi belirleyen sosyal alanlardır.

Kamu yönetimi alanında yaşanan paradigma değişimi ile refah devleti anlayışında yaşanan gelişmelerin yerel yönetimlere olan etkisi ile yerel yönetimler post-modern dönemde daha liberal, demokratik, vatanaş odaklı ve katılımcı bir yapıya sahip olmuştur. 1980'li yıllar itibariyle yerel yönetimlerde yaşanan reform ve dönüşümün en önemli nedenleri; "küreselleşme, kamu yönetiminde yeniden yapılanma, refah devletinden neo-liberal devlete geçiş ve modern kamu yönetiminden postmodern kamu yönetimine dönüşüm" gibi farklı yönetsel, siyasal, sosyyo-kültürel ve ekonomik değişkenlere bağl1 olarak açıklanabilmektedir (Doğan, 2016:81). 


\subsubsection{Yerel Yönetimlere Sosyal Yaklaşım}

Yerel yönetime bu farklı yaklaşımlar 20. Yüzyıl başlangıcından Menşevik ve Bolşeviklerin yerel sovyetler konusundaki uzun süren tartışmalarında kendini gösterdiği gibi; Avrupalı sosyalistler arasında da Sovyet devletinin temeli ve niteliği üstüne yürütülen sert ve amansız eleştirilerde de karşımıza çıkmaktadır. Avrupa sosyalizminin önde gelen isimlerinden Bernstein, yerel yönetime büyük önem vererek, onu-işçi sınıfı ve emekçi kesimlerde demokrasi deneyiminin yaygınlaştırılması yolu ile - sosyalizmi gerçekleştirmenin zorunlu bir ön koşulu olarak görmüştür.

Son yıllara kadar, belirli istisnalar dışında (İtalya gibi) uzun süre merkeziyetçi parti ve yönetim anlayışının (demokratik merkeziyetçiliğin) etkisi altında faaliyetlerini yürüten Yerel Marxizm Hareketi, günümüzde değişik ülkelerde farklı yapı ve yaklaşımlar göstermektedir. Ancak, liberal demokratik ülkelerde görülen bu hareketleri genel olarak eski Sovyetler Birliği ve sosyalist ilkelerdeki yerel yönetim sistemi yapılanmalarından ayırmak gerekir (Ökmen, 2015:9).

\section{BAĞIMSIZLIK SONRASI AZERBAYCAN CUMHURIYETİ'NDE DEVLET YAPILANMASI VE KAMU YÖNETIMI}

Azebaycan 1991 yılında bağımsızlığını ilan etmesi ile birlikte modern topluma uyum sağlamak amaciyla muhtelif reformları hayata geçirmeye başlamıştır. Bu reform çalışmalarının temel amacı; Demokratik bir ülke olarak Azerbaycan'ın uluslararası arenadaki diğer ülkelerle eşit koşullarda hareket edebilmesini sağlayabilmektir. Yapılan reformların hukuki kaynağı Azerbaycan Anayasası'dır. Bilindiği üzere anayasa; bir devletin temel özelliklerini, erkleri olan yasama, yürütme ve yargı organlarını, bu organların kuruluşunu, işleyişini ve birbirleri ile olan ilişkilerini belirleyen, kendisinin üstünde başka bir hukuk normu bulunmayan ve diğer hukuk normlarına dayanak oluşturan en üstün hukuk kurallarıdır (Mumcu, 1980:76). Anayasacılık hareketlerinin başladığı 18. yüzyılın sonlarından itibaren anayasanın işlevsel anlamı (en azından özgürlükçü demokrasilerde), devlet iktidarını sınırlandırmayı sağlayan meşru bir araç olmasıdır. Anayasa ile mevcut devlet iktidarının, devleti oluşturan temel erkler (organlar) arasında paylaştırılması ve bu organların sahip oldukları görev ve yetkiler aracılı̆̆ıla birbirlerini sınırlandırması, dengelemesi ve denetleyebilmesi anayasal devlet yönetimini ortaya çıkarmaktadır (Özbudun, 1992:20).

Azerbaycan Cumhuriyeti'nin bağımsızlığını ilan etmesinin ardından dönemin cumhurbaşkanı Haydar Aliyev başkanlığındaki Devlet Komisyonu tarafından ilk anayasası hazırlanmıştır. Bu anayasa 12 Kasım 1995 tarihinde yürürlüğe girmiş̧tir. Anayasaya göre devlet egemenliğinin tek kaynağı Azerbaycan halkıdır. Söz konusu halk, egemenlik hakkını, kendi rızasıyla seçtiği temsilciler (milletvekilleri) aracılığı (temsili demokrasi) kullanacaktır. Halkın seçtiği yetkili temsilcilerden başka hiç bir kimseye "halk adına konuşmak" ve "halk adına başvurma" gibi halkı temsil etme hakları tanınmamıştır. Ülke üzerinde halkın tamamını yansıtmayan hiçbir sosyal grubun, kişinin ya da örgütün egemenliğin kullanıcısı olamayacağı Anayasa'da (md.6) hüküm altına alınmıştır. Anayasaya göre Azerbaycan Devleti; yasal, üniter, laik ve demokratik bir cumhuriyettir. Devlet egemenliği ancak uluslararası anlaşmalardan doğan yükümlülüklerle sınırlandırılabilir. Daha önceden de belirtildiği üzere Azerbaycan'da devlet egemenliği, anayasada belirtilen kuvvetler ayrılı̆̆ı ilkesine dayanmaktadır (md. 7). Kuvvetler ayrılı̆̆ ilkesine göre her erk kendi temel görev alanında bağımsız bir şekilde faaliyette bulunurken diğer erkler ile de ilişki içerisindedir.

Azerbaycan'da temel erklerden olan yasama yetkisi, Azerbaycan Cumhuriyeti Milli Meclisine aittir. Yürütme yetkisi ise anayasa ile Cumhurbaşkanı'na verilmiştir. Son anayasal erk olan yargı yetkisi de Azerbaycan bağımsız mahkemelerine aittir. Azerbaycan devletinin başı olan Cumhurbaşkanı; silahlı kuvvetlerin başkomutanı, halk arasında birlikteliği sağlayan, iç ve dış ilişkilerde devleti temsil eden, yargı bağımsızlığı ile devletin toprak bütünlüğünün ve bağımsızlığının bir güvencesi olarak kabul edilmektedir (md. 8).

Azerbaycan anayasası; yaşam hakkı, mülkiyet hakkı, çalışma hakk1, düşünce ve vicdan özgürlüğü ile diğer temel hak ve özgürlükleri ayrıntılı bir şekilde düzenlemiştir. Anayasa'da kuvvetler ayrıllğ 1 ilkesi benimsenmiştir (md.7/3). Fakat Anayasa'nın 8. maddesinin 4. bendi bu ilke ile çelişki göstermektedir. Çünkü bu madde de Azerbaycan Cumhurbaşkanı'nın ülkenin yargı bağımsızlığının bir güvencesi olduğu belirtilmiştir. Ancak yargı organının faaliyetlerini gerçekleştirirken tüm demokratik ve özgür ülkelerde olduğu gibi bağımsız olması gerekmektedir (Turhan, 1993:12). Buradan hareketle Azerbaycan Anayasasına göre yürütme organının başı olan cumhurbaşkanının aynı zamanda yargı bağımsızlığının güvencesi olarak gösterilmesi "hukuk devleti” ilkesine 
uygun düşmemektedir. Merkezileşmiş bir anayasal sistemi öngören Azerbaycan Anayasası ile demokrasiye geçiş reformunun asli unsurlarından birisi olarak Anayasa Mahkemesi kurulmuştur.

\subsection{Anayasa'da 2002 Yılında Yapılan Değişiklikler}

Anayasa, bir devletin en önemli kanunudur. Anayasa değişikliği demokrasi, millet ve Azerbaycan Cumhuriyeti için çok önemli bir kazanımdır.Referanduma katılım oranının ise yüzde 88,43'e ulaştmıştır. Halkoylamasına 8 ayrı bölümde sunulan değişikliklerden seçim sisteminde değişikliğe ilişkin madde yüzde 96,82 oranında "Evet", yüzde 2,7 oranında "Hayır" oyu aldı."Cumhurbaşkanının görevlerini meclis başkanı yerine başbakana devretmesine" ilişkin değişikliğe yüzde 96,84 oranında "Evet", yüzde 2,89 oranında "Hayır" oyu verildi.

Söz konusu değişiklikler, insan hakları vekilinin (ombudsman) seçilmesi, vatandaşların Anayasa Mahkemesi'ne başvuru hakkının tanınması, mahkemelerin gerekli davaları Anayasa Mahkemesi'ne göndermesi, temyiz mahkemelerinin yapısı ve faaliyetleriyle ilgili konuları kapsıyor.Azerbaycan'ın temel hak ve özgürlüklerinin korunmasıyla ilgili Avrupa Sözleşmesi'ne katılması nedeniyle yapılan değişiklikler bölümünde ise söz konusu sözleşme çerçevesinde olağanüstü durumlarda gündeme gelen çeşitli askeri içerikli cezalandırmaların yumuşatılması,inançları nedeniyle askerlik hizmetini yapmak istemeyenlerin "alternatif bir askeri görev" yerine "alternatif bir görev" yapması yer alımıştır.

Üçüncü bölüm, vergiler, devlet bütçesi, genel af, yerel yöneticiler ve çeşitli düzeydeki yöneticilerin seçilmesi, tayini veya onayı konusunda halkoylaması yapılamayacağını öngörüyor. Milli Meclis üyelerinin belirleneceği seçimle ilgili bölümde ise "kısmi seçim sistemleri" yerine "seçim sistemi" denilmesini ve ilgili 89. maddenin 1. fikrasındaki 6 . bendin anayasadan çıkarılmıştır.

Cumhurbaşkanı seçimiyle ilgili bölümde, seçim için "üçte iki çoğunluk" yerine "yarıdan çok"un yeterli olması öngörülüyor. Milli Meclis'in yapılanması, görev ve sorumluluklarıyla ilgili konuların anayasada yer alması, "Devlet organlarının faaliyetlerinin geliştirilmesiyle ilgili değişiklikler" bölümünde bulunuyor. Bu maddede, ayrıca Meclis çalışma sistemine ilişkin değişikler, "cumhurbaşkanının görev ve yetkilerini Milli Meclis başkanı yerine başbakana devretmesi" ile anayasal değişiklik tekliflerinin sınırlandırılması oya sunulmuşve kabul edilmiştir.

Referandumda 7. bölümde sunulan değişiklikler, ülkedeki mahkeme sisteminde savcılık organlarının görev alanlarının genişletilmesini vedaha aktif çalışmalarını öngörüyor "Diğer değiş̧iklikler" bölümünde Nahcivan Özerk Cumhuriyeti anayasasının Azerbaycan Cumhurbaşkanı tarafından sunulmasının yanı sıra yerel yönetimlerin statüsü ve yerel seçimlerin kurallarının yasayla belirleneceği ifade edilmıştir.

\subsection{Anayasa Değişiklikleri}

Yedi yıl sonra Anayasası'nın 29 maddesinde 41 değişiklik yapılmıştır. 2009 yılı mart ayının 18-de yapılan referandumda öneriler seçmenler tarafından desteklenmiştir. Bu ilaveler ve değişiklikler insan hak ve özgürlüklerinin daha güvenli teminatına, devlet organlarının ve yerel yönetim organlarının etkinliğinin iyileştirilmesi, yargı bağımsızlığının artıılmasına hizmet etmektedir. Anayasanın 29 maddesine 41 ek ve değişiklikleri üç temel başlıkta sıralayabiliriz :birinci gruba insan hakları ve özgürlüklerinin daha da genişletilmesi ve korunması; ikinci gruba devletçilik alanında; üçüncü gruba yasama, yargı erklerine ve belediyelere ait maddelere önerilen ek ve değişiklikleri ait etmek olur. Anayasa değişikliğinden biri, cumhurbaşkanının görev süresiyle ilgili sınırlamanın kaldırılmasını öngörüyor. Referandumda, Azerbaycan anayasasının 101. maddesinde yer alan 'cumhurbaşkanının 2 defadan fazla seçilememesi' kararının kaldırılması teklif edilmiş ve kabul edilmiştir. Referanduma götürülen değişikliklerde savaş durumunda seçimlerin ertelenmesi hükmünün de yer aldığı, referandum sonucunda toplam 29 maddede değişiklik yapılmıştır. 


\subsection{Eylül 2016 Tarihli Anayasa Değişikliği}

Azerbaycan Cumhuriyeti Anayasası'nda 3. kez değişiklikler 26 Eylül 2016 tarihinde ülke Cumhurbaşkanı İlham Aliyev'in girişimi ile hayata geçirilmiştir. Anayasa'nın 23 maddesinde değişiklik yapılmış, aynı zamanda Anayasa metnine 6 madde eklenmiştir. Onları dört gruptan oluşmaktadır;

1. İnsan hak ve Özgürlüklerinin Korunması ve Geliştirilmesi,

2. Kurumların faaliyetlerinin modernize edilmesi ve kalitesinin sürekli iyileştirilmesini,

3. Devletler ve hükümetler arası uluslararası anlaşmaların imzalanması sisteminin iyileştirilmesi,

4. İnsan hak ve özgürlüklerinin korunmasında belediyelerin sorumluluğunun artırılması.

Cumhurbaşkanı İlham Aliyev'in önerisi ile halkoyuna sunulan anayasa değişikliğiyle Cumhurbaşkanı'nın görev süresinin 5 yıl iken 7 yıla çıkarılması, Cumhurbaşkanı seçilmede koşul olan "en az 35 yaş" sınırının kaldırılması, Cumhurbaşkanına, süresi dolmadan Cumhurbaşkanlığı seçimi ilan etme yetkisinin verilmesi öngörülmüştür.

Değişiklikler arasında "Cumhurbaşkanı birinci yardımcılığı" ve "Cumhurbaşkanı yardımcıları" makamları da oluşturulmuştur. $\mathrm{Bu}$ makamlara atamalar ve görevden almalar Cumhurbaşkanı tarafından yapılacaktır. Cumhurbaşkanı birinci yardımcısı, dokunulmazlık hakkına sahip olacak, Cumhurbaşkanı'nın olmadığ 1 durumlarda bütün yetkileri birinci yardımcısına verilecektir. Öncesinde bu görev başbakana verilmekteydi.

İnsan hak ve özgürlüklerinin korunması mekanizmasının iyileştirilmesi ile ilgilidir. Diğer değişikliklerden amaç siyasi kurum faaliyetlerinin geliştirilmesi, uluslararası ve hükümetlerarası uluslararası anlaşmaların imzalanması rejiminin daha da optimize etmektir. Anayasanın "Mülkiyet Hukuku" bölümüne, "Özel mülkiyet sosyal sorumluluk gerektirir" ve "Sosyal adalet ve toprakların verimli kullanılması amacıyla toprak mülkiyeti hukuku kanunla klsıtlanabilir" şeklinde hükümler eklenerek değişiklikler yapılmıştır.

\section{BAĞIMSIZ AZERBAYCAN CUMHURIYETINDE YEREL YÖNETIMLER VE REFORM ÇALIŞMALARI}

Azerbaycan yönetim sistemi içerisinde bulunan yerel yönetimler, yerel bir coğrafi alanda halka kamu hizmeti sunan, karar organları kanunda belirlenen şekilde yerel halk tarafından seçilerek iş başına gelen, idari ve mali özerkliğe sahip kamu tüzel kişilikleridir. Hem üniter hem de federal devletlerde demokrasinin yerleşikliği ile yerel yönetimlerin gücü ve etkinliği doğru orantılıdır. Hatta çoğu zaman yerel yönetimlerin gücüyle ülkenin ekonomik gelişmişliğinin de doğru orantılı olduğu söylenebilir. Daha yalın bir ifadeyle, yerel yönetimler ile iktisadi kalkınma ve yerel demokratikleşme arasında doğru orantılı bir ilişki bulunmaktadır. Hatta bazı aksi iddiaların da varlığına rağmen, yerel yönetimlerin ülke bütünlüğünün sağlanması ve sağlamlaştırılması hususunda önemli işlevleri olduğu düşünülmektedir. Çünkü demokrasinin bir gereği olarak yerel düzeyde kendi kendini yöneten ve yönetime katılım sağlayan halk, kendini halk sorunları ve çözüm önerileri hususunda geliştirmekte, elde ettiği birikimler ile de milli bütünlüğe entegre olmaktadır.

Azerbaycan'ın 1991 yılında kazandığı bağımsızlık öncesi ve özellikle geçen 200 yılına bakıldığında önce Çarlık Rusya'sının ardından da Sovyetler Birliği'nin hakimiyeti altında bulunduğu görülmektedir. Bunun neticesinde bugün ülkede yönetim yapısı, kültürü ve alt idari örgütleri ilgili dönemlerin (özellikle SSCB'nin) izlerini taşımaktadır. Çarlık Rusyası döneminde Azerbaycan'ın yönetim yapısı dönem dönem farklılıklar gösterse de "guberniya" (il/eyalet) sistemi ve general gubernatörler (askeri valiler) idari yapıya genel olarak her zaman hakim olan sistem ve örgütlenmelerdir. Sovyetler Birliği dönemindeyse komünist partisinin hakimiyetindeki "rayon" (il/ilçe) sistemi, "yerel sovyet" örgütlenmesi ve icra komiteleri idari yapının en önemli oluşumlarıdır (Elma, 2012:110). 
Tablo 1. Azerbaycan SSC’de Yerel Sovyetler (1978 Anayasas1)

\begin{tabular}{|c|c|}
\hline Sovyetlerin Sayısı & 1.294 \\
\hline Sovyetlerdeki Üye Oranı & $\% 48.9$ \\
\hline Kadın Üye Oranı & $\% 46$ \\
\hline SBKP Üyesi ve Aday Üyelerin Oranı & $\% 45$ \\
\hline Komsomol Üye Oranı & $\% 20$ \\
\hline İş̧ilerin Oranı & $\% 36$ \\
\hline Kolhoz Üyeleri Oranı & $\% 28$ \\
\hline Sanayi Sektöründe Çalışanların Oranı & $\% 16$ \\
\hline Tarım Sektöründe Çalışanların Oranı & $\% 56$ \\
\hline Tarımda Devlet Sektöründe Çalışanların Oranı & $\% 28$ \\
\hline Yüksek Okul ve Lise Mezunlarının Oranı & $\% 73$ \\
\hline
\end{tabular}

Kaynak: Ergun, 1994:76.

Batılı gelişmiş ülkelerinin idari sistemleri değerlendirildiğinde, devletlerin birçoğunda yerel yönetimlerin kamu hizmetlerinin hayata geçirilmesi hususunda merkezi yönetimlerden çok daha fazla rol üstlendiği, böylelikle de kamu hizmetlerinin daha verimli ve etkili bir şekilde gerçekleştirildiği anlaş1lmıştır. 30 Eylül 1991'de bağımsızlığına kavuşan Azerbaycan Cumhuriyeti de bu gelişmelerin dışında kalmamış, hem yerel yönetimler hem de merkezi idare ile ilgili reformların hayata geçirilmesi için önemli adımlar atmıştır. Fakat bu reformlar süreklilik göstermediği için istenilen neticeler tam olarak elde edilememiştir.

Azerbaycan Cumhuriyeti, idari açıdan "rayon" adı verilen ve Türkiye'deki merkezi idarenin taşra birimi olan "il"lere karşılık gelen temel "yönetim bölgelerine" ayrılmıştır. Bugün mevcut olan rayonların yönetim sistemi ve idari sınırları esas olarak Sovyetler Birliği döneminden kalmadır. SSCB döneminde sosyalist sistem ideolojisinin gereği olarak rayonlarda işçi ve köylülerin seçilmiş temsilcilerinden oluşan ve kendisine "Halk Deputatları Sovyetleri" adı verilen meclisler, yönetimin asli organlarını oluşturmaktaydı. Ancak yönetsel iktidar bu meclislerden ziyade Komünist Partisi ve taşra teşkilatlarının hakimiyetindeydi. Azerbaycan'ın bağımsızlığını ilan etmeden kısa bir süre öncesinde (1 Haziran 1991) dönemin cumhurbaşkanı Ayaz Muttalibov tarafından yayınlanan kararname ile "Halk Deputatlar Sovyetleri" ortadan kaldırılmadan, "İcra Hakimliği" makamı kurulmuştur. Cumhurbaşkanı tarafından atanan bu kişiler yerel yürütme yetkilerini münhasıran elinde bulundurmuşlardır (TIKA, 1996). Klasik bir birim olan "Halk Deputatları Sovyeti”'nin sorumluluğu ise bütçenin kabul edilmesi ile yasada belirtilen diğer bazı karar ve önlemlerin onaylanması ile sınırlandırılmıştır. İcra hakimleri, görevlerini yerine getirirken kendilerine yardımcı olmak üzere iki ya da üç kişiyi yardımcı olarak atayabilmektedir. Merkezi idarenin taşra birimleri içerisinde icra hakimlerine bağlı olarak hukuk, eğitim, kültür, gençlik spor, polis, sağlık, ekonomi, maliye, ulaştırma, nakliyat, tarım, sosyal ve insani yardım alt idareleri bulunmaktadır. Bu idari birimlerde personel istihdamı (ataması), yetki karmaşasına sebebiyet verecek şekilde merkezi yönetim başkent teşkilatı (ilgili bakanlık) ya da merkezi idarenin taşra teşkilatı temsilcisi olan icra hakimi tarafından ayrı ayrı veya her ikisi tarafından ortak bir şekilde yapılmaktadır (Hasanoğlu, 2008:83).

Azerbaycan Cumhuriyetinde yeni ekonomik ilişkilerin hayata geçirilmesi ve güçlü bir ekeonomik sistemin tesis edilebilmesi için ülkenin idari sisteminde köklü reformların hayata geçirilmesi gerekiyordu. Reformların yapılması amacıyla 29 Aralık 1998 tarihinde Azerbaycan Cumhurbaşkanı'nın imzaladığı fermanla Devlet Komisyonu kurulmuştur. Devlet Komisyonunun esas olarak demokratikleşme ve serbest pazar ekonomisi ile ilgili hayata geçirilecek reformlarda devlet yönetiminin verimliliğini ve etkinliğini arttırması ile ekonominin gelişmesi için uluslararası standartlara uygun hukuki alt yapının tesis edilmesine yardımcı olacak şekilde çalışmalar yapması gerekmektedir (Rehimli, 2011:53). 
Anayasaya (md.7) göre; “Azerbaycan Devleti, demokratik, hukuki, laik ve üniter Cumhuriyettir”. Azerbaycan'da demokratik bir devlet inşaası hedeflendiği için demokratikleşmenin esas unsurlarından olan yerel demokratik yönetim ilkesi benimsenmiştir (Azerbaycan Cumhuriyeti Anayasas1, 2017:7). Bununla birlikte yerel yönetimler sadece anayasa ile merkezi yönetimin verdiği ve devrettiği yetkileri kullanabilir.

Azerbaycan Anayasası'na göre yerel halka sunulan kamu hizmetleri iki farklı şekilde gerçekleştirilmektedir;

a) Merkezi idarenin taşra teşkilatı olarak yerel yürütme hakimiyeti organları,

b) Yerel yönetim birimi olarak belediyeler.

Merkezi idarenin taşra birimlerinin iş ve eylemlerini eşgüdümleştiren yerli yürütme hakimiyetlerinin başkanları (merkezi idarenin taşra birimi amirleri) Azerbaycan Cumhurbaşkanı tarafından göreve atanır ve yine cumhurbaşkanı tarafından görevden alınır. Bu kişilerin görev ve yetkileri cumhurbaşkanı tarafından belirlenmektedir (An. md.124).

Anayasanın IX. Faslı "Belediyeler" başlığını taşımaktadır (Azerbaycan Cumhuriyeti Anayasası, 2017:7). Bu fasıl altı maddeden meydana gelmektedir. İlgili maddelerde belediyelerin teşkili, yetkileri, karar alma süreçleri, belediyelerin işinin teşkili ve belediyelerin bağımsızlığının teminatı ile ilgili hususlar düzenlenmiştir. Belediye yönetimleri seçim ile göreve gelir. Belediyelerin statüleri ve seçimlerine ilişkin usul ve esaslar kanunla düzenlenir. Belediyelerin statüsü ile ilgili olarak anayasada (md.27);

\section{"Belediyelere seçimler, vatandaşlarına kanunla belirlenmiş seçim hakları temin edilmekle; genel, eşit, doğrudan seçim hakları esasında serbest, şahsi, gizli oy verme yolu ile hayata geçirilir. Belediye seçimleri Belediye Seçimlerinin Kuralları Hakkında Azerbaycan Cumhuriyeti Kanununa uygun olarak gerçekleştirilir. Azerbaycan Cumhuriyetinin devlet organları belediye seçimlerinin demokratik olarak hayata geçirilmesine teminat verirler", hükümlerine yer verilmiştir.}

Azerbaycan'da yerel seçimler 5 yılda bir yapılmaktadır. Dolayısıyla belediyelerin görev süresi beş yıldır. Seçim sonuçlarının kesinlik kazanmasından sonra yapılan ilk toplantı günü, belediye üyelerinin görevleri ile ilgili yetkilerini kullanmaya başladıkları ilk andır. Üyelerin yetkileri, belediyelerin yetkilerinin olduğu seçim dönemi ile sınırlıdır. Yerel seçimlerin süresinin sona ermesine en geç 120 gün kala yeni seçim süreci başlar. Belediye seçimleri için seçme ve seçilme yaşı 18 yaşının tamamlamış olmasıdır. Hukuk muhafaza organlarının çalışanları, hakimler, İcra hakimiyeti organlarında çalışan görevliler, subaylar ve din adamları belediye üyesi seçilemezler. Üyeler, seçmenler tarafından doğrudan ve gizli oy ile seçilirler.

Belediye görevlerini kurmuş olduğu sürekli ve diğer komisyonlar aracıllğıyla yerine getirmektedir. Toplantılar için belediye başkanı üyelere davette bulunur. Belediye toplantılarında şu konular görüşülerek karara bağlanabilir (Azerbaycan Cumhuriyeti Anayasas1, 2017:54);

- Belediye meclis üyelerinin sahip olduğu yetkilerinin tanınması ve kanunla belirtilen durumlarda mevcut yetkilerinin sınırlandırılması ya da sona erdirilmesi,

- Belediyeler tarafından çalışma iç tüzüklerinin onaylanması; belediye başkanı ile yardımcılarının kurulan sürekli ve diğer komisyonlara seçilmesi ile yerel vergilerin ve ödentilerin belirlenmesi,

- Belediye bütçesinin ve uygulama raporlarının onaylanması; belediyeye ait malların tasarrufu ile ilgili hususlarda kararlar alınması,

- Yerel çevre programlarının, sosyal savunma ve sosyal kalkınma programları ile yerli ekonomik kalkınma programlarının kabul ve icra edilmesi.

Belediyeler, ülkedeki hukuk normlarına uygun olarak, kendisine verilen yetki çerçevesinde, yerel ve ortak nitelikli sorunları serbest ve bağımsız bir şekilde çözüme kavuşturma hakkına sahiptirler. Bu hakları çerçevesinde faaliyetlerini gerçekleştirebilmek için mülk edinme, bağımsız bir bütçeye sahip olma, kendi içerisinde idari birimler tesis etme, bu birimlerde personel çalıştırma, vb. gibi hakları bulunmaktadır (Mecek, 2018:69). Azerbaycan'da anayasa ve kanunlar olmak üzere hukuki mevzuat esas alındığında yerel yönetim birimi olan belediyelerin temel niteliklerini kısaca aşağıdaki şekilde sıralayabiliriz (Elma ve Ökmen, 2013:7374);

- Belediyeler halk egemenliğinin yerel düzeyde temsil edildiği organlardır.

- Belediyelerin karar organları halk tarafından seçilerek işbaşına gelir.

- Belediye başkanı, belediye meclisi tarafından belirlenir. 
- Belediyeler özerk kuruluşlardır. Bu özerklik anayasa ve belediye kanununda açıkla belirtilmektedir.

- Belediyeler anayasa ile kendisine verilen görevlerini meclis toplantıları, sürekli ve diğer komisyonlar ile yürütme organları aracılığı ile hayata geçirirler.

- Belediyeler diğer ülke belediyeleri ile işbirliği yapabileceği gibi ülkede yer alan diğer belediyeler ile de birlikler kurabilirler.

- Belediyeler bağımsız olarak mevzuata uygun bir şekilde bütçelerini belirleme ve kendi iç işleyişlerini düzenleme haklarına sahiptirler.

1999 yılından 2009 yılına kadar geçen on y1llık sürede ülkede köylerden kentlere kadar 2757 belediye inşa edilmişdir. Fakat 2009 yılında ülkenin özellikle kuzey ve güney bölgelerinde yapılan yerel yönetim reformları çerçevesinde bir çok belediyenin birleştirilmesi, kapatılması ve yenilerinin inşa edilmesi ile ülkede belediye sayıs1 1718'e düşmüştür (BINA QHT Alyans1, 2011:14-15).

Azerbaycan' da, belediyelerin gelişerek büyümesi için yapılacak faaliyetler yalnız Azerbaycan için değil, aynı zamanda bağımsızlıklarını yeni kazanan diğer Türk Cumhuriyetleri için de büyük önem taşımaktadır. Bağımsızlıklarını yeni kazanan Türk Cumhuriyetleri içinde belediye modeli ilk olarak Azerbaycan' da uygulanmıştır. Azerbaycan Belediyelerinin elde edeceği başarı diğer Türk Cumhuriyetleri için örnek teşkil edecektir (Zengin, 2010:100).

20. Yüzyılın sonuna gelindiğinde bağımsızlığına tekrar kavuşmuş bir ülke olan Azerbaycan `ın hızlı gelişmesine doğal kaynakları, coğrafi konumu, verimli toprak ve iklim koşulları önemli katkı sağlamaktadır. Azerbaycan' da uygulanan ekonomik yapılanma sürecinde reformlar ve kalkınma hamleleri sonrası kendine özgü yeni bir model "Azerbaycan Modeli” ortaya çıkmıştır.

\section{SONUÇ}

20. Yüzyılda Azerbaycan'da dört ayrı sistemin egemen olduğu görülmektedir. İlk olarak Çarlık Rusya'sı ülke üzerinde hakimiyet kurmuştur. Sonrasında ülke kısa süreli bir bağımsızlık dönemi yaşamıştır. Ülkenin yeniden işgal edilmesiyle birlikte bir sosyalist yönetim dönemi ülkede hakim olmuştur. Ağır asimilasyon sürecinin yaşandığı bu dönem sonrasında 1991 yılında SSCB dağılmıştır. Son olarak bu gelişmeler sonucu 1991 yılında Azerbaycan yeniden bağımsız bir devlet olarak varlığını sürdürmeye başlamıştır.

Azerbaycan'ın 1991 yılının Ekim ayında bağımsızlı̆ıını kazanması çok büyük bir tarihi olay olmakla beraber, Azerbaycan halkının yaşamında yeni bir başlanğıç noktası oluşturmuştur. Bağımsızlığına yeniden kavuşan Azerbaycan Cumhuriyeti demokratik, sivil, liberal değerlere dayanan devlet yapısının oluşturulmasını ana amaç olarak belirlemiştir. Bu bağlamda çağdaş toplumlara uyum sağlamak amacıyla yönetim alanında muhtelif reformları hayata geçirmeye başlamıştır. Bu reformların temel amacı; eski Sovyet yönetiminden miras kalan hantal devlet yapısından kurtularak, daha etkin, verimli ve demokratik yeni bir yönetim yapısına sahip olmaktır.

Azerbycan, üç temel sebepten dolayı yeni dünya düzeninde dikkatleri üzerinde çekmiştir. Bu sebepler;

1. Jeostratejik yönden Kuzey Kafkas'ın ve Orta Asya'nın giriş kapısı konumunda olması,

2. Orta Asya devletlerinin Avrupa ya geçiş noktası üzerinde bulunması,

3. Büyük miktarlarda petrol ve doğal gaz rezervlerine sahip olmasıdır.

SSCB'nin dağılması ve "Soğuk Savaş"ın sona ermesi uluslararası sisteminde nicel ve niteliksel olarak muhtelif değişikliklerin yaşanmasına sebep olmuştur. Post-sovyet mekanında yeni bağımsız devletlerin ortaya çıkması, onların bölgesel ve küresel gelişmelerin önemli aktörlerine dönüşmesi bu değişikliklere örnek olarak gösterilebilir. Azerbaycan jeopolitik konumu ve doğal kaynakları ile Soğuk Savaşın sona ermesi neticesinde yeni dönemde dünyanın dikkat merkezine yeleşmiştir. Bağımsızlı̆̆ını elde etmesi ile birlikte uluşlararası sistemin önemli subjelerinden biri haline gelmiştir. SSCB'nin dağılmas1 1990'l1 yıllarda dünyada görülen en önemli ekonomik ve politik değişim sürecidir. Bu dönemde bölgede yeni bir süreç yaşanmaya başlamıştır. Bunun en temel nedeni Sovyetler Birliği'nin sahip olduğu geniş coğrafi alan ve bu alanda bir arada yaşayan çok sayıdaki topluluğun varlığıdır. Bu sebeple bu coğrafyalarda oluşan değişimler bütün dünyayı doğrudan etkilemiştir.

Azerbaycan her geçen gün idari, siyasi ve ekonomik açıdan daha çok güçlenerek bölgesel bir aktör olmaya ve güçlü bir dünya devletine dönüştürülmektedir. İktisadi kalkınma hızına göre Azerbaycan sadece bölgesinde 
değil, dünyada da ilk sıralarda yer almaktadır. Azerbaycan Cumhuriyeti nin kamu yönetimi reformu ile ilgili hattının belirlenmesi ve gerçekleștirilmesi tam anlamıla Azerbaycan`ın milli lideri 1993-2003 yılları arasında ülkeyi yöneten Haydar Aliyev`in ismi ile bağlıdır. Haydar Aliyev'in karizmatik kişiliği ve engin devlet tecrübesi Azerbaycan`ın devlet yönetimin sağlıklı bir şekilde kurulmasına olanak sağlamıştır. Azerbaycan ekonomisi 20 yıl öncesine göre $\% 300$ oranında daha fazla gelişim göstermiştir. Sanayi alanındaki ilerlemeler aynı derecede dinamik bir şekilde artış göstermiş̧ir. Azerbaycan ekonomisi Güney Kafkasya bölgesinin toplam ekonomisinin $\% 75$ ini oluşturmaktadır.

Azerbaycan, Sovyetler Birliğinin dağılmasından sonra her yönü ile karmaşık bir süreç içerisine girmiştir. Bağımsızlık sonrası Ermenistan ile yaşanan savaş, bu süreci daha da karmaşıklaştırarak içinden çıkılmaz bir hale getirmiştir. Topraklarının önemli bir kısmı işgal altında kalmıştır. Bu sebeple bahsedilen dönemlerde ülke nüfusun yerleşim tercihlerinde ve yerleşme düzeninde çok hızlı bir şekilde değişim meydana gelmiştir. Tüm bu olumsuzluklara rağmen Azerbaycan söz konusu süreçten yılmadan, etkin plan ve programlarla çalışarak içinde bulunduğu karmaşıklıktan büyük ölçüde kurtulmayı başarmıştır.

\section{KAYNAKÇA}

AKÇAKAYA, Murat (2017), "Yeni Yönetim Anlayişinin Yerel Yönetimlere Yansimalari”, Gazi Üniversitesi Sosyal Bilimler Dergisi, S.4(9), ss.105-130.

ALKAN, Haluk ve ÇIFTÇIOĞLU, Hüseyin (2007), "Yerel Siyasette Belediye Meclisi ve Siyasi Parti Örgütleri: Göksun Örneği”, Kocaeli Üniversitesi Sosyal Bilimler Enstitüsü Dergisi, S.14(2), ss.1-27.

AZERBAYCAN CUMHURIYETI ANAYASASI (2017), Hukuk Neşriyatı, Bakü.

BAĞÇE, Emre (1999), “Küreselleşme, Devlet Ve Demokrasi”, Amme İdaresi Dergisi, S.32(4), ss 3-14.

BILGIN, Kamil Ufuk ve HASANOV, Mürteza (2002), Azerbaycan'da Kamu Yönetiminde Yerel Yönetimlere İlişkin Demokratik Gelişmeler, "Bağımsızlıklarının 10. Yılında Türk Cumhuriyetleri.

BİNA QHT Alyansı (2011), “Azerbaycan'da Belediyelerin Mevcut Durumuyla Ilgili Rey”, Belediyelerin İnkişafı Namına QHT Alyansı, Bakü.

GÜLER, Birgül Ayman (2001), "Devletin Yeniden Yapılandırılması", Kuvayı Milliye Dergisi Ocak-Subat , S.238, ss 1-11. http://80.251.40.59/politics.ankara.edu.tr/bguler/pdf/yonetisim.pdf (Erişim Tarihi: 03.08.2018).

BOZKURT, Ömer ve ERGUN, Turgay (1998), Kamu Yönetimi Sözlüğü, TODAİE Yayını, Ankara.

BÜYÜKBAYKAL, Ceyda (2004), Türkiye'de Televizyon Alanında Küresel Yerel Birlikteliği: Cnn Türk Ve Cnbc-E Örneği, Istanbul Üniversitesi Iletişim Fakültesi Yayınları, İstanbul.

CANPOLAT, Hasan (2010), "Türkiye'de Son Dönem Yerel Yönetim Reformlarının Yeni Kamu Isşletmeciliği ve Küreselleşme Bağlamında Değerlendirilmesi”, Türkiye'de Yerel Yönetimlerin Sorunları ve Geleceği, Seçkin Yayıncılık, Ankara, 2. Baskı.

CASTELLS, Manuel (2005), Enformasyon Çağı: Ekonomi, Toplum ve Kültür, Ağ Toplumunun Yükselişi (Çev. Ebru Kılıç), Istanbul Bilgi Üniversitesi Yayınları, İstanbul.

ÇITCI, Oya (1989), Yerel Yönetimlerde Temsil, TODAİE Yayınları, Ankara.

DAHL, Robert (2001), Demokrasi Üstüne, Phoenix Yayınları, Ankara.

DECENTRALIZATION: RETHINKING GOVERNMENT (1999), Entering the 21'st Century World Development Report, Oxford University Press, Oxford.

DEMIR, Ömer ve ACAR, Mustafa (1997), Sosyal Bilimler Sözlüğü, Vadi Yayınları, Ankara.

DOĞAN, Kadir Caner (2016), "Postmodern Kamu Yönetimi, Yerel Yönetimler ve Katılım: Yerel Yönetişim Odaklı Bir Yaklaşım”, İGÜSBD, S.3(2), ss.73-97.

EKE, Ali Erkan (1985), “Ana Kent Yönetimi ve Yönetimler Arası İlişkiler: Batı Deneyimi ve Türkiye”, Amme İdaresi Dergisi, S.18(4), TODAİE Yayınları, Ankara. 
ELMA, Fikret (2012), “Azerbaycan'da İdari Yapının Dönüşümü”, Uluslararası Üç Deniz Havzası Ülkeleri Ortak Yönetim Kültürü ve Yeniden Yapılanma Sorunları Sempozyumu, Kamu Araştırmaları Vakfı ve Aydın Üniversitesi Ortak Yayını, İstanbul.

ELMA, Fikret ve ÖKMEN, Mustafa (2013), Türk Dünyasinda Yerel Yönetimler - Yapısal İşlevsel Görünüm ve Dönüşüm Süreci, Türk Dünyasi Belediyeler Birliği Yayini, İstanbul.

EREN, Erol (2001), Örgütsel Davranış ve Yönetim Psikolojisi, Beta Yayınları, İstanbul, 7.bask1.

ERKUL, Hüseyin (2010), Türkiye’de Yerel Yönetimler, Detay Yayıncılık, Ankara.

EROĞUL, Cem (1999), Devlet Yönetimine Katılma Hakkı, İmge Kitabevi, Ankara, 2. Bask1.

ERYILMAZ, Bilal (2007), Kamu Yönetimi, Okutman Yayınc1lık, İstanbul.

ERYILMAZ, Bilal (2011), Kamu Yönetimi, Düşünceler - Yapılar - Fonksiyonlar - Politikalar, Okutman Yayınc1lı, Ankara.

GÜLER, Birgül Ayman (1997), “Küreselleşme ve Yerelleşme", Çağdaş Yerel Yönetimler Dergisi, S.6(3), ss.62-77.

HASANOĞLU, Mürteza (2001), “Küreselleşmenin Devlet Yönetimine Etkileri”, Saysştay Dergisi, S.43(72), ss.123-134.

HASANOĞLU,Mürteza(2008), "Azerbaycan Cumhuriyeti'nde Devletin Yeniden Yapılandırılması ve Yerel Yönetimlerin Güçlendirilmesi" , Sayıştay Dergisi S.69 ), ss.73-90.

HELD, David ve McGREW, Anthony (2008), Küresel Dönüşümler Büyük Küreselleşme Tartışması, Phoenix Yayınevi, Ankara.

KALAYCIOĞLU, Ersin (1984), Çağdaş Siyasal Bilim, Osman Aykoç Matbası, İstanbul.

KAYA, Niyazi (1992), Yerel Yönetimler Araştırma Grubu, TODAİE Yayınları, Ankara.

KELEŞ, Ruşen (1980), Kentbilim Terimleri Sözlüğ̈̈, Türk Dil Kurumu Yayını, Ankara.

KELEŞ, Ruşen (1992), Yerinden Yönetim ve Siyaset, Cem Yayınevi, Ankara.

KELEŞ, Ruşen (2011), Yerinden Yönetim ve Siyaset, Cem Yayınevi, İstanbul, 7. Basım.

KIŞLALI, Ahmet Taner (1984), “Eski Yunanda Demokrasi ve Demokratik Düşünce”, Amme İdaresi Dergisi, S.17(1), ss.63-77.

MECEK, Mehmet (2018), "Azerbaycan'ın Devlet Yapısı ve Taşra Yönetiminde Merkez - Yerel İlişkileri", Bitlis Eren Üniversitesi Sosyal Bilimler Enstitüsü Dergisi, S.7(1), ss.51-77.

MENGİ, Ayşegül (1998), Avrupa Birliğinde Bölgeler Karşısında Yerel Yönetimler, İmaj Yayıncılık, Ankara.

MILLER, David, COLEMAN, J. ve CONNOLLY, W. (1995), Blackwell'in Siyasal Düşünce Ansiklopedisi, Ümit Yayınları, Ankara.

MUMCU, Ahmet (1980), Siyasal Tarihe Giriş, Turhan Kitabevi, Ankara.

ÖKMEN, Mustafa (2015), "Yerel Yönetim Teorisi: Ekonomik, Sosyal ve Siyasal Yaklaşımlar", Yerel Yönetimlerde Güncel Gelişmeler (Ed. Mustafa Ökmen), Ekin Yayınevi, Bursa.

ÖZBUDUN, Ergun (1992), Türk Anayasa Hukuku, Yetkin Yayınları. Ankara. 2. Bask1.

ÖZKALP, Enver ve KIREL, Çiğdem (2001), Örgütsel Davranış, Anadolu Üniversitesi AÖF Yayınları, Eskişehir, 6. Bask1.

ÖZTEKIN, Ali (2002), Yönetim Bilimi, Siyasal Kitabevi, Ankara.

PARLAK, Bekir ve ÖKMEN, Mustafa (2010), Kuramdan Uygulamaya Yerel Yönetimler: İlkeler, Yaklaşımlar ve Mevzuat, Alfa Aktüel Yayınları, Bursa, 2. Baskı.

PEKER, Ömer (1995), Yönetimi Geliştirmenin Sürekliliği, TODAİE Yayını, Ankara.

PUSTU, Yusuf (2005), "Yerel Yönetimler ve Demokrasi”, Sayıştay Dergisi, S.57, ss.121-134.

PÜSKÜLLÜOĞLU, Ali (1995), Türkçe Sözlük, Yapı Kredi Yayınları, İstanbul. 
REHIMLI, Recep (2011), Azerbaycan Devlet Personel Yönetimi, Kültür Ajans Yayınları, Ankara.

SAĞLAM, Serdar (2007), "Küreselleşmeye Yaklaşımlar”, Genç Sosyal Bilim Forumu AGORA, S.13, ss.7.

SEKIZINCI BEŞ YILLIK KALKINMA PLANI (2001), "Yerel Yönetimler Özel İhtisas Komisyonu Raporu”, DPT Yayınları, Ankara.

ŞAYLAN, Gencay (1998), Demokrasi ve Demokrasi Düşüncesinin Gelişmesi, TODAİE Yayınları, Ankara.

TEKELI, İlhan (1983), “Yerel Yönetimlerde Demokrasi ve Türkiye'de Belediyelerin Gelişimi”, Amme İdaresi Dergisi, S.16(2), ss.3-22.

TERLEMEZ, Birol (2001), Toplam Kalite Yönetiminde Sürekli Değişme ve Gelişme, Yaklaşım Dergisi, S.9(101), ss.236-242.

TİKA (1996), Azerbaycan Ülke Raporu, TİKA Yayınları, Ankara.

TORTOP, Nuri (1994), Mahalli İdareler, Yargı Yayınları, Ankara.

TORTOP, Nuri(1993), Yönetim Bilimi, S Yayınları, Ankara.

TORTOP, Nuri ve AYKAÇ, Burhan, YAYMAN, Hüseyin ve ÖZER, Mehmet Akif (2008), Mahalli İdareler, Nobel Yayın Dağıtım, Ankara.

TORTOP, Nuri, AKTAN, Tahir ve ERGUN, Turgay (2000), Kamu Yönetimi (Ed. Ziyaettin Bildirici), Anadolu Üniversitesi AÖF Yayınları, Eskişehir, 4.Bask1.

TURHAN, Mehmet (1993), Hükümet Sistemleri, Gündoğan Yayınları, Ankara.

TUTAR, Hasan (2000), Küreselleşme Sürecinde İşletme Yönetimi, Hayat Yayıncılık, İstanbul.

ULUSOY, Ahmet ve AKDEMIR, Tekin (2010), Yönetimlerarası Transferler: Teori ve Türkiye Uygulaması, Türkiye'de Yerel Yönetimlerin Sorunları ve Geleceği (Ed. Nihat Falay, Ahmet Kesik, Murat Çak, Mehmet Karakaş), Seçkin Yayıncılık, Ankara 2. Bask1.

ÜSTÜN, Sadi (1999), Yerel Yönetim Terimleri Sözlüğü, İçişleri Bakanlığı Kontrolörü, Mahalli İdareler Derneği Yayını, Ankara.

YALÇINDAĞ, Selçuk (1995), Yerel Yönetimler, Sorunlar, Çözümler, TÜSİAD Yayınları, İstanbul.

YALÇINDAĞ, Selçuk (1999), Federal Almanya'da ve Türkiye'de Yerel Yönetimler, TODAİE Yayınları, Ankara.

ZENGIN, Eyüp (2010), Piyasa Ekonomisine Geçiş Sürecinde Azerbaycan, İTO Yayını, İstanbul.

ZENGINGÖNÜL, Oğul (2004), Yoksulluk Gelişmişlik ve İşgücü Piyasaları Ekseninde Küreselleşme, Adres Yayınları, Ankara. 